Check for updates

Cite this: RSC Adv., 2021, 11, 15245

\title{
Novel electroblowing synthesis of tin dioxide and composite tin dioxide/silicon dioxide submicron fibers for cobalt(II) uptake $\uparrow$
}

\author{
Johanna Paajanen, (D) * Saara Weintraub, (D) Satu Lönnrot, Mikko Heikkilä, (D) \\ Marko Vehkamäki, Marianna Kemell, (D) Timo Hatanpää, (D) Mikko Ritala (D) \\ and Risto Koivula (D)
}

\begin{abstract}
Nanoscale $\mathrm{SnO}_{2}$ has many important properties ranging from sorption of metal ions to gas sensing. Using a novel electroblowing method followed by calcination, we synthesized $\mathrm{SnO}_{2}$ and composite $\mathrm{SnO}_{2} / \mathrm{SiO}_{2}$ submicron fibers with a $\mathrm{Sn}: \mathrm{Si}$ molar ratio of $3: 1$. Different calcination temperatures and heating rates produced fibers with varying structures and morphologies. In all the fibers $\mathrm{SnO}_{2}$ was detected by XRD indicating the $\mathrm{SnO}_{2} / \mathrm{SiO}_{2}$ fibers to be composite instead of complete mixtures. We studied the $\mathrm{Co}^{2+}$ separation ability of the fibers, since ${ }^{60} \mathrm{Co}$ is a problematic contaminant in nuclear power plant wastewaters. Both $\mathrm{SnO}_{2}$ and $\mathrm{SnO}_{2} / \mathrm{SiO}_{2}$ fibers had an excellent $\mathrm{Co}^{2+}$ uptake with their highest uptake/ $/ K_{d}$ values being $99.82 \% / 281000 \mathrm{~mL} \mathrm{~g}^{-1}$ and $99.79 \% / 234000 \mathrm{~mL} \mathrm{~g}^{-1}$, respectively. Compared to the bare $\mathrm{SnO}_{2}$ fibers, the $\mathrm{SiO}_{2}$ component improved the elasticity and mechanical strength of the composite fibers which is advantageous in dynamic column operation.
\end{abstract}

Received 26th February 2021 Accepted 16th April 2021

DOI: 10.1039/d1ra01559a

rsc.li/rsc-advances nanoparticles ${ }^{25}$ and the structural stability ${ }^{24}$ and mechanical strength ${ }^{28}$ of the fibers.

For removal of heavy metal ions from aqueous solutions, there are plenty of techniques such as chemical precipitation, ion exchange, adsorption, membrane filtration, electrochemical methods and phytoremediation. ${ }^{29,30}$ Adsorption has certain advantages over the other methods including high removal efficiency even at low concentrations, cost-effectiveness, simple design and less production of toxic sludge. ${ }^{29,31}$ Adsorbents comprise both organic and inorganic materials which may be synthetic or of natural origin, such as agricultural by-products. For example, titanium(Iv) iodovanadate particles have been utilized for $\mathrm{Pb}^{2+}$ and $\mathrm{Hg}^{2+}$ separation ${ }^{32}$ and coco-peat biomass for $\mathrm{Pb}^{2+}, \mathrm{Cd}^{2+}, \mathrm{Cu}^{2+}$ and $\mathrm{Ni}^{2+}$ removal. ${ }^{33}$ Inorganic submicron and nanofibers could be excellent adsorbents for a variety of industrial applications. Inorganic fibers have a large specific surface area due to their high surface-to-volume ratio and often form porous structures which can lead to a good adsorption capacity. Zirconium dioxide submicron fibers have performed well in flow-through column operation and shown better mechanical stability, less pressure build-up in the column and faster adsorption kinetics than the corresponding granules. ${ }^{34}$ Submicron and nanofibers can also be an eco-friendly alternative for the purification of nuclear power plant (NPP) wastewaters, since they can markedly reduce the volume of solid radioactive waste that requires a permanent repository.

The most common method to prepare polymeric or inorganic submicron and nanofibers is electrospinning. In this technique, a high voltage is applied to a precursor solution
Department of Chemistry, University of Helsinki, P.O. Box 55, FI-o0014, Finland. E-mail: johanna.paajanen@helsinki.fi

$\dagger$ Electronic supplementary information (ESI) available. See DOI: 10.1039/d1ra01559a 
containing a polymer, solvent(s) and for example a metal salt, depending on the desired fiber composition. During the electrospinning process, repulsive electrostatic forces cause the polymer chains to stretch and form fibers that are deposited on a grounded collector. Via post-electrospinning calcination, the polymer may be removed and the final fibrous product, typically a metal oxide, is formed. Different precursor solutions and operational parameters allow the control of the properties and morphology of the fibers. ${ }^{35}$ Electrospinning is therefore a simple and cost-efficient method and upscalable for industry. ${ }^{36-39}$ Solution blowing (airbrushing) method in contrast uses pressurized gas to draw fibers from the precursor solution. ${ }^{40}$ Solution blowing offers even 15 times faster production rate than electrospinning ${ }^{\mathbf{4 1}}$ but it tends to result in bundles of aligned fibers whereas electrospinning yields an entanglement of individual, mainly un-aligned fibers. ${ }^{\mathbf{4 2 , 4 3}}$ In electroblowing, the fibers are formed by both electrostatic force and air flow and hence the technique combines electrospinning and solution blowing and their advantages. Moreover, electroblowing enables 2.5 times faster solution feeding rate and thus fiber production rate than solution blowing. ${ }^{\mathbf{4 1 , 4 4}}$ Compared to electrospinning, the additional air flow in electroblowing permits the use of more viscous precursor solutions ${ }^{45}$ and produces fibers with smaller diameters and fewer beads. ${ }^{46}$ It should be feasible to scale up electroblowing for industry, similarly to electrospinning.

To tackle climate change, global energy production is increasingly based on clean low-carbon power including nuclear power. However, the production of nuclear energy generates radioactive fission and activation products that pose a risk to human health and environment without proper treatment of nuclear waste effluents. Among the activation products, ${ }^{60} \mathrm{Co}$ caused by steel corrosion is one of the most hazardous ones due to its rather long half-life of 5.3 years and high gamma decay energies of 1.17 and $1.33 \mathrm{MeV} .{ }^{47}$ Removal of ${ }^{60} \mathrm{Co}$ is therefore essential to diminish workers' radiation exposure, to reduce radioactive emissions to aquatic systems and to create safe waste forms for the final disposal. However, the separation of this radionuclide is quite difficult owing to its low concentration in the liquid waste of NPPs $\left(402 \mathrm{~Bq} \mathrm{~L}^{-1}{ }^{60} \mathrm{Co}\right.$ in floor drain water, Loviisa NPP, Finland). ${ }^{48}$ The process for its uptake has to be very selective, since generally the liquid waste contains large amounts of inactive metal ions (e.g. $37 \mathrm{mg} \mathrm{L}^{-1} \mathrm{Na}^{+}$in floor drain water, Loviisa NPP, Finland). ${ }^{48}$

In this research, we prepared $\mathrm{SnO}_{2}$ and composite $\mathrm{SnO}_{2} / \mathrm{SiO}_{2}$ submicron fibers by the electroblowing technique and calcination. We also studied the ability of the fibers to remove ${ }^{57} \mathrm{Co}^{2+}$ from an aqueous solution. To investigate the effect of $\mathrm{SiO}_{2}$ on both the structure and $\mathrm{Co}^{2+}$ uptake performance of the $\mathrm{SnO}_{2}$ fibers, we added $25 \mathrm{~mol} \%$ of silicon in the synthesis solution of the composite fibers. The structure and morphology of all the fibers were characterized and their $\mathrm{Co}^{2+}$ removal capability was studied. To the best of our knowledge, this is the first report on the electroblowing synthesis of $\mathrm{SnO}_{2}$ and $\mathrm{SnO}_{2} / \mathrm{SiO}_{2}$ submicron fibers and on their $\mathrm{Co}^{2+}$ uptake. This is also the first report on the uptake of metal ions by fibrous $\mathrm{SnO}_{2}$ and $\mathrm{SnO}_{2} / \mathrm{SiO}_{2}$.

\section{Experimental}

\subsection{Materials}

The precursor solutions for the electroblowing experiments were prepared from $\mathrm{SnCl}_{4} \cdot 5 \mathrm{H}_{2} \mathrm{O}$ ( $\geq 98 \%$, Sigma-Aldrich), tetraethoxysilane (TEOS, $\quad \mathrm{Si}\left(\mathrm{C}_{2} \mathrm{H}_{5} \mathrm{O}\right)_{4}, \quad 98 \%$, Sigma-Aldrich), polyvinylpyrrolidone (PVP, $\left(\mathrm{C}_{6} \mathrm{H}_{9} \mathrm{NO}\right)_{n}, M_{\mathrm{w}}=1300000$, Alfa Aesar), $\mathrm{N}, \mathrm{N}$-dimethylformamide (DMF, $\mathrm{C}_{3} \mathrm{H}_{7} \mathrm{NO}, \geq 99.9 \%$, Sigma-Aldrich) ethanol $\left(\mathrm{C}_{2} \mathrm{H}_{5} \mathrm{OH}, 96 \mathrm{vol} \%\right.$, GPR RECTAPUR $)$ and deionized water. In the uptake experiments ${ }^{57} \mathrm{CoCl}_{2}, \mathrm{Co}\left(\mathrm{NO}_{3}\right)_{2} \cdot 6 \mathrm{H}_{2} \mathrm{O}(98 \%$, SigmaAldrich), $\mathrm{NaNO}_{3}$ ( $\geq 99 \%$, VWR Chemicals), $\mathrm{NaCl}$ (99.75\%, Fisher Chemical), $\mathrm{CaCl}_{2}$ (fused, granular, Fisher Chemical), $\mathrm{HCl}$ (1 M, Oy FF-Chemicals Ab), NaOH (1 M, Reag. Ph. Eur., VWR Chemicals) and deionized water were used. A stock solution of $5 \mathrm{kBq} \mathrm{mL} L^{-1}$ ${ }^{57} \mathrm{Co}^{2+}$ was prepared by dissolving ${ }^{57} \mathrm{CoCl}_{2}$ in $1 \mathrm{mM} \mathrm{HCl}$.

\subsection{Synthesis of the $\mathrm{SnO}_{2}$ and $\mathrm{SnO}_{2} / \mathrm{SiO}_{2}$ fibers}

$\mathrm{SnO}_{2}$ and $\mathrm{SnO}_{2} / \mathrm{SiO}_{2}$ fibers were synthesized by electroblowing a solution comprising the tin or tin and silicon precursors, PVP and solvents followed by calcination. For the synthesis of $\mathrm{SnO}_{2}$ fibers, a certain mass of $\mathrm{SnCl}_{4} \cdot 5 \mathrm{H}_{2} \mathrm{O}$ was dissolved in deionized water and then mixed with DMF and 18 wt\% PVP/EtOH solution. The mass fractions of the constituents in the solution were $10 \mathrm{wt} \%$ for $\mathrm{SnCl}_{4} \cdot 5 \mathrm{H}_{2} \mathrm{O}, 9 \mathrm{wt} \%$ for PVP, $11 \mathrm{wt} \%$ for $\mathrm{H}_{2} \mathrm{O}, 39 \mathrm{wt} \%$ for EtOH and $31 \mathrm{wt} \%$ for DMF. For the preparation of $\mathrm{SnO}_{2} / \mathrm{SiO}_{2}$ fibers, $\mathrm{SnCl}_{4} \cdot 5 \mathrm{H}_{2} \mathrm{O}$ was dissolved in deionized water and then mixed with DMF, 14 wt\% PVP/EtOH solution and TEOS. The mass fractions of the constituents in the solution were $10 \mathrm{wt} \%$ for $\mathrm{SnCl}_{4} \cdot 5 \mathrm{H}_{2} \mathrm{O}, 2 \mathrm{wt} \%$ for TEOS, $7 \mathrm{wt} \%$ for PVP, $11 \mathrm{wt} \%$ for $\mathrm{H}_{2} \mathrm{O}, 40 \mathrm{wt} \%$ for EtOH and $30 \mathrm{wt} \%$ for DMF. The solutions were stirred at room temperature until they became clear and homogeneous.

For the electroblowing, a self-assembled apparatus was used. ${ }^{49}$ In a typical experiment, $12 \mathrm{~mL}$ of precursor solution was withdrawn into a syringe and a $27 \mathrm{G}$ (inner diam. $0.21 \mathrm{~mm}$ ) needle was attached to the syringe. The syringe was placed on a syringe infusion pump (KD Scientific Legato ${ }^{\circledR} 101$ ) and the solution feed rate was set to $15 \mathrm{~mL} \mathrm{~h}^{-1}$. This feed rate is 4 to 500 times as high as reported for the electrospinning of $\mathrm{SnO}_{2}$ and $\mathrm{SnO}_{2} / \mathrm{SiO}_{2}$ fibers. ${ }^{21-24,26,50,51}$ The needle was pushed through a $3 \mathrm{~mm}$ metal adapter of a box enclosing a cylindrical side collector and a planar back collector at $80 \mathrm{~cm}$ distance, both being made of a metal wire mesh. The potential difference between the needle and collectors was set to $15 \mathrm{kV}$ with a high voltage power source, and compressed air was delivered through the adapter at a rate of $30 \mathrm{NL} \min ^{-1}$. The solution jet erupted from the needle tip was deposited as fibers on the grounded collectors and additional drying air was delivered to the box at a rate of $40 \mathrm{NL} \mathrm{min}^{-1}$ to enhance solvent evaporation and to control the relative humidity within the box $(\leq 20 \%)$. The as-electroblown fibrous mats were detached from the collectors and calcined in an air furnace at 400,450 and $500{ }^{\circ} \mathrm{C}$ for 4 hours with a heating rate of $1^{\circ} \mathrm{C} \mathrm{min}^{-1}$ in order to remove the polymer and to form the desired ceramic material. The as-electroblown $\mathrm{SnO}_{2} / \mathrm{SiO}_{2} / \mathrm{PVP}$ fibers were also calcined at $400{ }^{\circ} \mathrm{C}$ for 4 hours with heating rates of 5 and $10{ }^{\circ} \mathrm{C} \mathrm{min}{ }^{-1}$. The yields of $\mathrm{SnO}_{2}$ and 
$\mathrm{SnO}_{2} / \mathrm{SiO}_{2}$ fibers were at best 0.54 and $0.53 \mathrm{~g}$ per hour of electroblowing, respectively.

\subsection{Characterization of the $\mathrm{SnO}_{2}$ and $\mathrm{SnO}_{2} / \mathrm{SiO}_{2}$ fibers}

Morphology of the fibers was analysed by imaging with secondary electrons (SE) and transmitted electrons (TE) with a Hitachi S-4800 field emission SEM. Prior to the imaging with secondary electrons, the samples were placed on carbon tape and sputter coated with a $4 \mathrm{~nm}$ layer of $\mathrm{Au} / \mathrm{Pd}$ alloy to improve conductivity. Elemental analysis of the fibers including elemental mapping was conducted with an Oxford INCA 350 energy dispersive X-ray spectroscopy (EDX) system connected with the Hitachi S-4800. A Quanta 3D 200i focused ion beam SEM (FIB-SEM) equipped with an Oxford INCA 350 EDX system and an Omniprobe nanomanipulator was used for extracting single $\mathrm{SnO}_{2} / \mathrm{SiO}_{2}$ fibers onto a copper grid for cross-sectional elemental mapping. The average diameters of the fibers and their grains were determined with a Fiji ImageJ software. The crystallinity of the fibers was analysed with a PANalytical X'Pert PRO MPD X-ray diffractometer using $\mathrm{Cu} \mathrm{K} \alpha$ radiation and focusing optics. The fiber samples were powdered prior to the analysis. The mean crystallite sizes and their weight ratios were determined from the XRD data by the Rietveld refinement using a MAUD software. ${ }^{52}$ Thermogravimetric analysis (TGA) of the aselectroblown fibers was conducted with a NETZSCH STA 449 F3 Jupiter® system using a heating rate of $10{ }^{\circ} \mathrm{C} \mathrm{min}^{-1}$ in a temperature range of 25 to $1000{ }^{\circ} \mathrm{C}$ in a flow of air (50 mol\%) and $\mathrm{N}_{2}$ (50 mol\%, the purge gas). The specific surface area and porosity of the fibers were measured by $\mathrm{N}_{2}$ physisorption at $77 \mathrm{~K}$ with a Micromeritics ASAP 2020 Gas sorption analyser.

\section{$2.4 \mathrm{Co}^{2+}$ uptake studies}

2.4.1 Effect of calcination temperature and heating rate. $\mathrm{Co}^{2+}$ uptake by the $\mathrm{SnO}_{2}$ and $\mathrm{SnO}_{2} / \mathrm{SiO}_{2}$ fibers calcined at different temperatures and with different heating rates was studied at a pH of $6.20 \mathrm{mg}$ of ground fibers was weighed into $20 \mathrm{~mL}$ scintillation vials and $10 \mathrm{~mL}$ of $0.01 \mathrm{M} \mathrm{NaNO}_{3}$ solution containing $30 \mathrm{~Bq} \mathrm{~mL}^{-1}{ }^{57} \mathrm{Co}^{2+}$ was added into the vials. The $\mathrm{pH}$ of the solution was adjusted to 6 with a small volume of $\mathrm{NaOH}$. The samples were equilibrated in a constant rotary mixer (50 rpm) for 24 hours after which the equilibrium $\mathrm{pH}$ was measured. The samples were phase separated by centrifugation at $4000 \mathrm{rpm}(2100 \mathrm{~g})$ and syringe filtration (Acrodisc LC PVDF, $0.2 \mu \mathrm{m})$. The ${ }^{57} \mathrm{Co}^{2+}$ uptake efficiency of each sample was determined by pipetting $5 \mathrm{~mL}$ of the filtrate into a scintillation vial and measuring the remaining activity with a PerkinElmer Wallac Wizard $3^{\prime \prime} 1480$ automatic gamma counter. The ${ }^{57} \mathrm{Co}^{2+}$ uptake results are presented by means of distribution coefficient $K_{\mathrm{d}}$, that describes the distribution of the adsorbate between the adsorbent and solution:

$$
K_{\mathrm{d}}=\frac{\left(c_{0}-c_{\mathrm{eq}}\right) V}{c_{\mathrm{eq}} m}
$$

where $c_{0}\left(\mathrm{~Bq} \mathrm{~L}^{-1}\right)$ is the initial concentration, $c_{\mathrm{eq}}\left(\mathrm{Bq} \mathrm{L}^{-1}\right)$ is the equilibrium concentration, $V(\mathrm{~mL})$ is the volume of the solution and $m(\mathrm{~g})$ is the mass of dry adsorbent. Background activity was subtracted before the calculations. Uncertainty of $K_{\mathrm{d}}$ was calculated using the error propagation law.

2.4.2 Effect of $\mathbf{p H}$. $\mathrm{Co}^{2+}$ uptake by $\mathrm{SnO}_{2}$ fibers calcined at $500{ }^{\circ} \mathrm{C}$ was investigated in the $\mathrm{pH}$ range of 4 to 12 . The batch samples were prepared as described above and the $\mathrm{pH}$ of the solution was adjusted with a small volume of either $\mathrm{HCl}$ or $\mathrm{NaOH}$. The equilibrium $\mathrm{pH}$ was measured after the 24 hours of constant rotary mixing. The ${ }^{57} \mathrm{Co}^{2+}$ uptake by the fibers was calculated by means of the distribution coefficient $K_{\mathrm{d}}$ as described above.

2.4.3 Effect of coexisting ions. Selectivity of $\mathrm{SnO}_{2}$ fibers towards $\mathrm{Co}^{2+}$ in the presence of competing ions $\mathrm{Na}^{+}$and $\mathrm{Ca}^{2+}$ was examined. The batch samples were prepared as reported
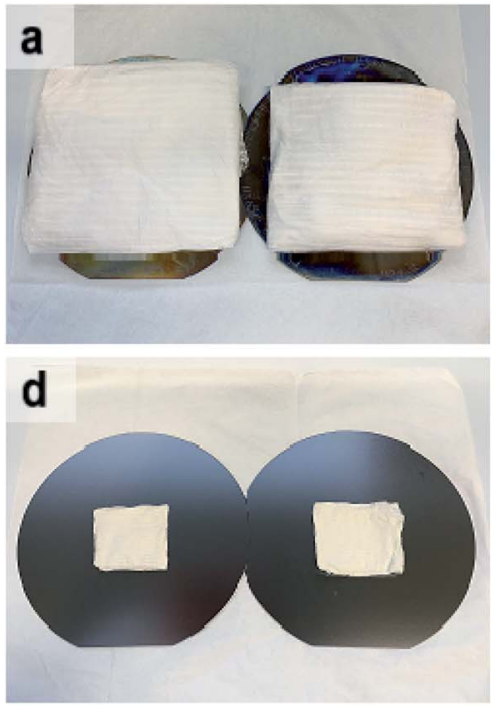
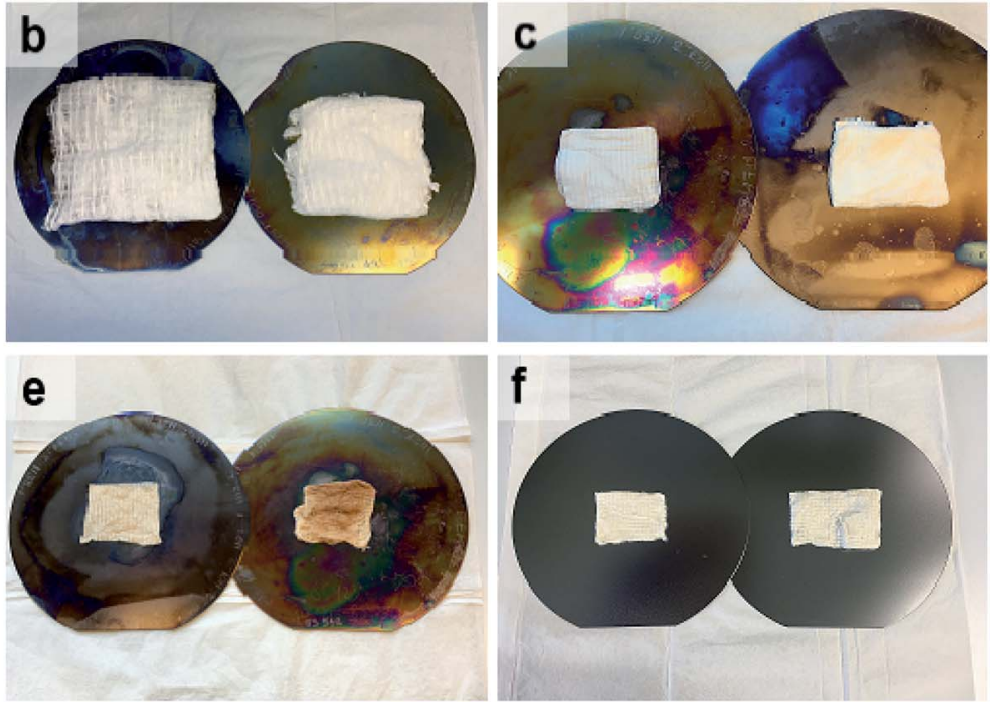

Fig. 1 As-electroblown $\mathrm{SnO}_{2} / \mathrm{PVP}$ (a) and $\mathrm{SnO}_{2} / \mathrm{SiO}_{2} / \mathrm{PVP}$ (b) fibers, $\mathrm{SnO}_{2}$ fibers calcined at $400{ }^{\circ} \mathrm{C}$ (c) and $500{ }^{\circ} \mathrm{C}$ (d) as well as $\mathrm{SnO} / \mathrm{SiO} 2$ composite fibers calcined at $400{ }^{\circ} \mathrm{C}$ (e) and $500^{\circ} \mathrm{C}$ (f) on $150 \mathrm{~mm}$ silicon wafers. In the calcination, a heating rate of $1^{\circ} \mathrm{C} \mathrm{min}{ }^{-1}$ was used. The calcined fiber mats are shrunken due to the removal of the polymer. 


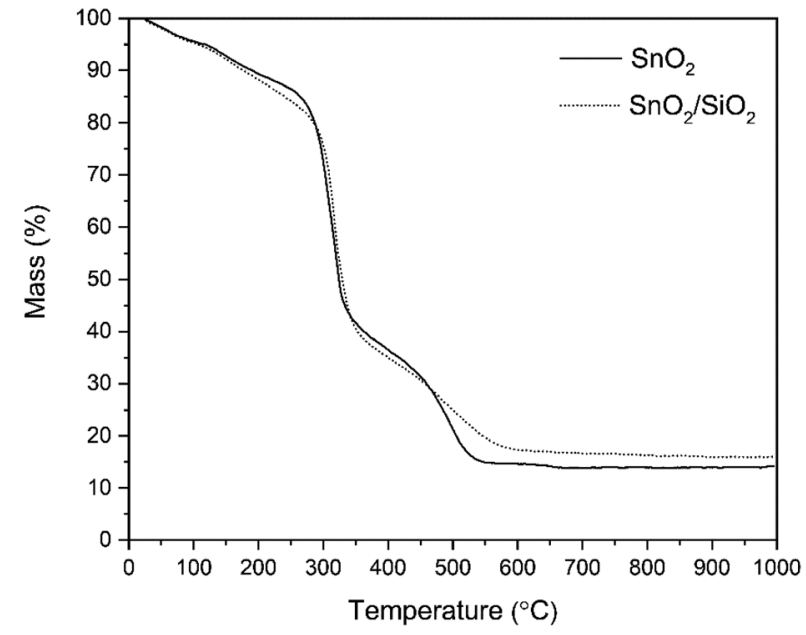

Fig. 2 TG curves of as-electroblown $\mathrm{SnO}_{2} / \mathrm{PVP}$ and $\mathrm{SnO}_{2} / \mathrm{SiO}_{2} / \mathrm{PVP}$ fibers in air (50 mol\%) and $\mathrm{N}_{2}(50 \mathrm{~mol} \%$, the purge gas).

above and the initial $\mathrm{pH}$ was adjusted to 6 . Four concentrations of the competing ion were used: $0.001,0.01,0.1$ and $1 \mathrm{M}$ for $\mathrm{NaCl}$, and $0.001,0.01,0.1$ and $0.5 \mathrm{M}$ for $\mathrm{CaCl}_{2}$. The ${ }^{57} \mathrm{Co}^{2+}$ removal by the fibers was calculated as the distribution coefficient $K_{\mathrm{d}}$.

2.4.4 EDX analysis. Elemental analysis of the $\mathrm{SnO}_{2}$ and $\mathrm{SnO}_{2} / \mathrm{SiO}_{2}$ fibers after adsorption of $\mathrm{Co}^{2+}$ including elemental mapping was conducted. For the analysis, $20 \mathrm{mg}$ of fibers was weighed into $20 \mathrm{~mL}$ scintillation vials and $10 \mathrm{~mL}$ of $0.01 \mathrm{M}$ $\mathrm{NaNO}_{3}$ solution containing $1 \mathrm{mM}$ non-radioactive $\mathrm{Co}^{2+}$ $\left(\mathrm{Co}\left(\mathrm{NO}_{3}\right)_{2} \cdot 6 \mathrm{H}_{2} \mathrm{O}\right)$ was added into the vials. The $\mathrm{pH}$ of the solution was adjusted to 6 . The samples were equilibrated for $24 \mathrm{~h}$, phase separated and dried in an oven at $70{ }^{\circ} \mathrm{C}$ overnight.

\section{Results and discussion}

\subsection{Electron microscopy and TG analysis of the $\mathrm{SnO}_{2}$ and $\mathrm{SnO}_{2} / \mathrm{SiO}_{2}$ fibers}

Photographs of as-electroblown $\mathrm{SnO}_{2} / \mathrm{PVP}$ and $\mathrm{SnO}_{2} / \mathrm{SiO}_{2} / \mathrm{PVP}$ fibers as well as $\mathrm{SnO}_{2}$ and $\mathrm{SnO}_{2} / \mathrm{SiO}_{2}$ fibers calcined at 400 and $500{ }^{\circ} \mathrm{C}$ are shown in Fig. 1. The calcined fiber mats have shrunk because the polymer has been removed. Except for the $\mathrm{SnO}_{2} / \mathrm{SiO}_{2}$ fibers calcined at $400{ }^{\circ} \mathrm{C}$, the colour of the calcined fibers is white, which implies no major amounts of carbon residues i.e. efficient combustion of the polymer. In regard to the $\mathrm{SnO}_{2} / \mathrm{SiO}_{2}$ fibers with a brownish hue, both the lower calcination temperature of $400{ }^{\circ} \mathrm{C}$ and the presence of $\mathrm{SiO}_{2}$ probably cause incomplete combustion of the PVP. Based on TG analysis, ${ }^{53}$ combustion of the bare PVP fibers is not complete until at $700{ }^{\circ} \mathrm{C}$ and hence there may be carbon residues in the calcined fibers although not necessarily to a visible extent. The amorphous $\mathrm{SiO}_{2}$ phase in the composite fibers may be more prone to retain the amorphous polymer compared to the crystalline $\mathrm{SnO}_{2}$ fibers and $\mathrm{SiO}_{2}$ and PVP are known to form hydrogen bonds. ${ }^{54,55}$
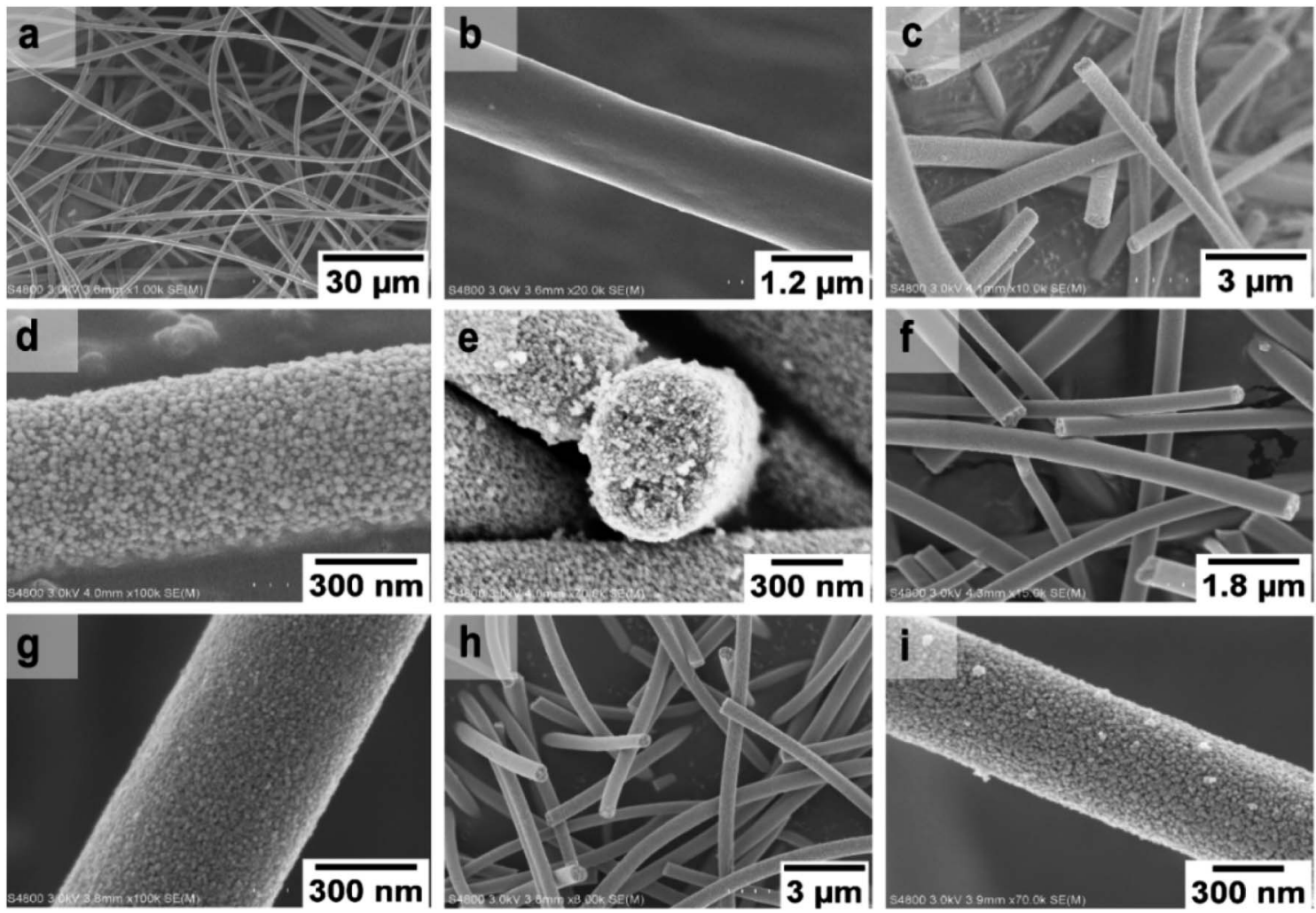

Fig. 3 FESEM images at low (a) and high (b) magnification of uncalcined $\mathrm{SnO}_{2} / \mathrm{PVP}$ fibers and $\mathrm{SnO}_{2}$ fibers calcined at $400{ }^{\circ} \mathrm{C}$ ( $\mathrm{c}$ to e), $450{ }^{\circ} \mathrm{C}$ ( $\mathrm{f}$ and g) and $500{ }^{\circ} \mathrm{C}$ (h and i). 


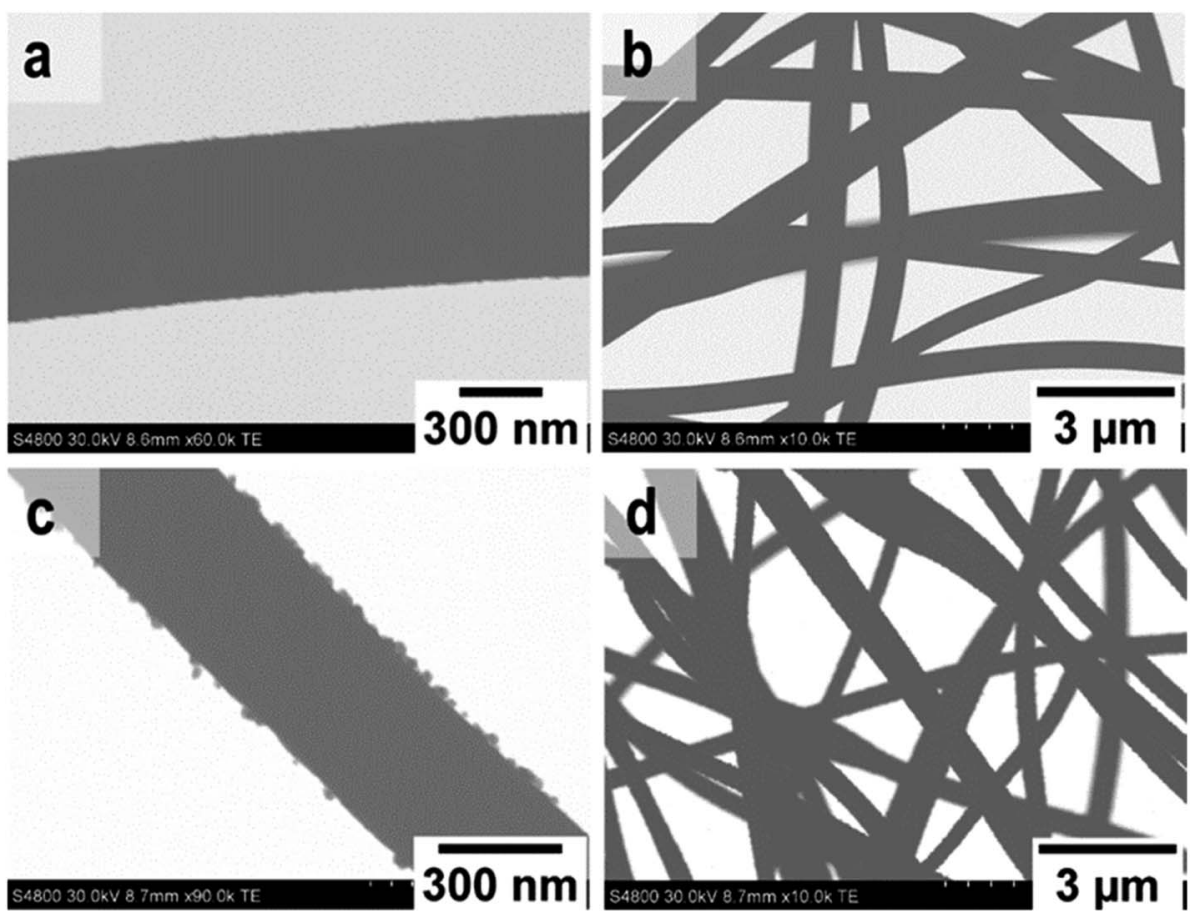

Fig. 4 TE images at low and high magnification of $\mathrm{SnO}_{2}$ fibers (a and b) and $\mathrm{SnO}_{2} / \mathrm{SiO}_{2}$ composite fibers (c and d) calcined at $500{ }^{\circ} \mathrm{C}$.

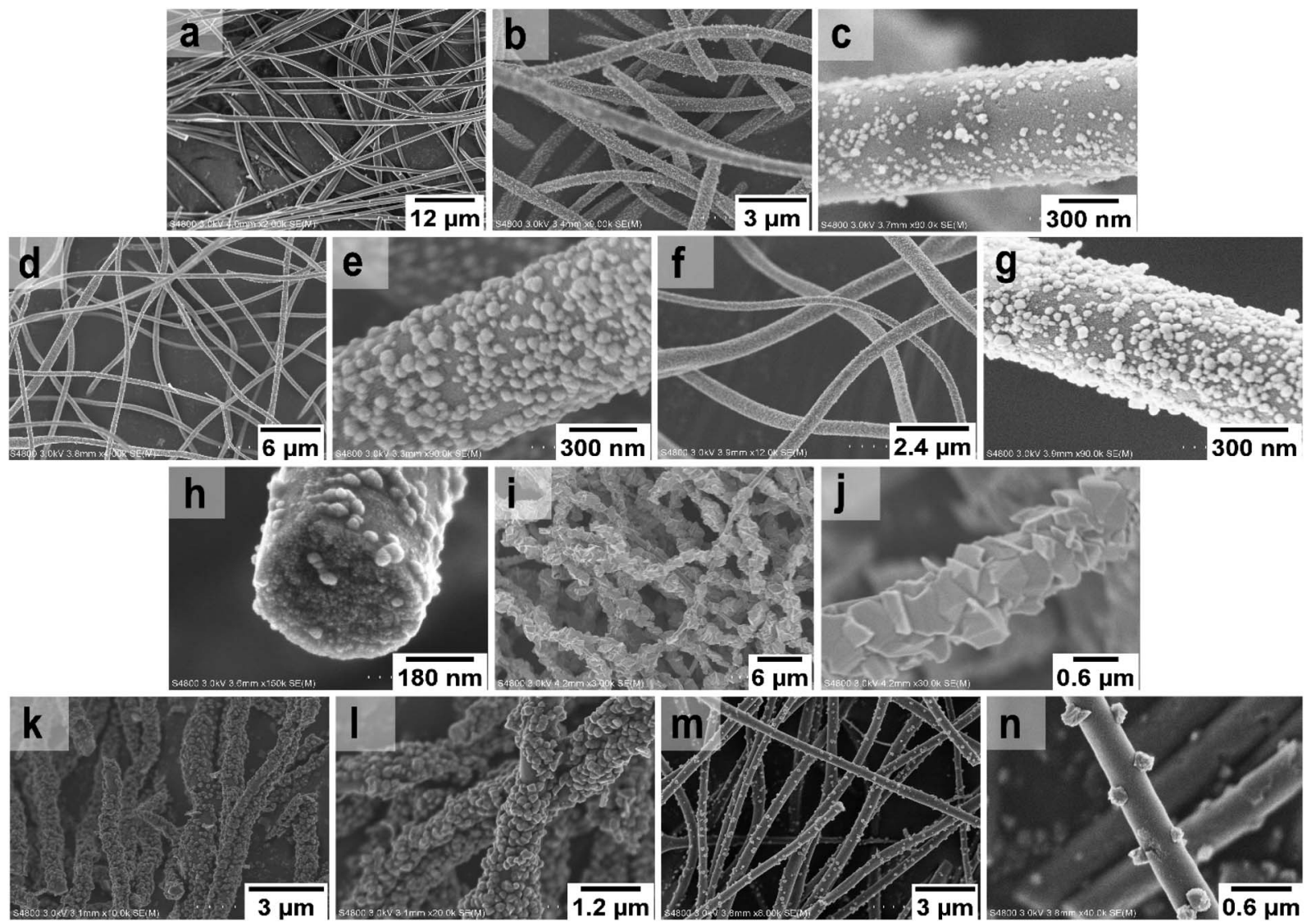

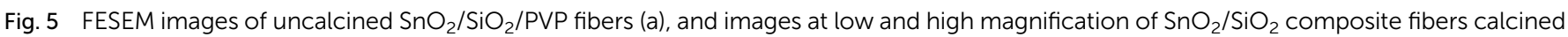
at $400{ }^{\circ} \mathrm{C}(\mathrm{b}$ and $\mathrm{c}), 450^{\circ} \mathrm{C}$ ( $\mathrm{d}$ and e) and $500^{\circ} \mathrm{C}$ ( $\mathrm{f}-\mathrm{j}$ ) with a heating rate of $1^{\circ} \mathrm{C} \mathrm{min}^{-1}$ as well as $\mathrm{SnO}_{2} / \mathrm{SiO}_{2}$ composite fibers calcined at $400{ }^{\circ} \mathrm{C}$ with heating rates of $5^{\circ} \mathrm{C} \mathrm{min}^{-1}(\mathrm{k}$ and $\mathrm{l})$ and $10^{\circ} \mathrm{C} \mathrm{min}^{-1}(\mathrm{~m}$ and $\mathrm{n})$. 
According to the TG analysis of the as-electroblown $\mathrm{SnO}_{2} /$ PVP and $\mathrm{SnO}_{2} / \mathrm{SiO}_{2} / \mathrm{PVP}$ fibers (Fig. 2), the combustion of the PVP in the $\mathrm{SnO}_{2} / \mathrm{SiO}_{2}$ composite fibers is not complete until at $600{ }^{\circ} \mathrm{C}$ whereas it is complete at $500{ }^{\circ} \mathrm{C}$ in the case of the bare $\mathrm{SnO}_{2}$ fibers. Furthermore, it can be seen that the mass of pure $\mathrm{SnO}_{2}$ is $c a .15 \%$ and the mass of pure $\mathrm{SnO}_{2} / \mathrm{SiO}_{2}$ is $c a .20 \%$ of the mass of the as-electroblown material. The measured weights of the calcined $\mathrm{SnO}_{2}$ and $\mathrm{SnO}_{2} / \mathrm{SiO}_{2}$ fibers are in line with this, also for the lowest calcination temperature of $400{ }^{\circ} \mathrm{C}$. This implies a more effective combustion of the polymer in the calcining furnace which is probably due to a higher oxygen content as the furnace atmosphere comprises air instead of air $/ \mathrm{N}_{2}$ mixture and a long 4 hour duration of the calcination. Owing to the presence of $\mathrm{SiO}_{2}$, the calcined $\mathrm{SnO}_{2} / \mathrm{SiO}_{2}$ composite fiber mats were elastic and could be bent without causing fractures to them. The $\mathrm{SnO}_{2}$ fiber mats were more brittle and fractured when bent. The differences in elasticity between the $\mathrm{SnO}_{2}$ and $\mathrm{SnO}_{2} / \mathrm{SiO}_{2}$ fibers are demonstrated in the video "Bending experiments with the $\mathrm{SnO}_{2}$ and $\mathrm{SnO}_{2} / \mathrm{SiO}_{2}$ fibers".

FESEM images of the uncalcined $\mathrm{SnO}_{2} / \mathrm{PVP}$ fibers and $\mathrm{SnO}_{2}$ fibers calcined at 400, 450 and $500{ }^{\circ} \mathrm{C}$ are presented in Fig. 3. The average diameter of the uncalcined fibers containing the polymer was $1.5 \mu \mathrm{m}$ whereas the average diameter of the calcined fibers was $560 \mathrm{~nm}$. The morphology of the calcined $\mathrm{SnO}_{2}$ fibers was similar regardless of the calcination temperature. The fibers seemed to have a uniform structure that consisted of roundish grains approximately $20 \mathrm{~nm}$ in diameter, although there was some variation between individual grains. A similar granular structure has also been reported for both dense $\mathrm{e}^{21,23,26,50}$ and hollow ${ }^{22,56}$ electrospun $\mathrm{SnO}_{2}$ nanofibers. The dense character of the fibers in the current study is proved by the FESEM image of a fiber cross-section (Fig. 3e) and was verified by imaging with transmitted electrons (Fig. 4a and b).

FESEM images of the uncalcined $\mathrm{SnO}_{2} / \mathrm{SiO}_{2} / \mathrm{PVP}$ fibers and $\mathrm{SnO}_{2} / \mathrm{SiO}_{2}$ fibers calcined at 400,450 and $500{ }^{\circ} \mathrm{C}$ with a heating rate of $1{ }^{\circ} \mathrm{C} \mathrm{min}{ }^{-1}$ as well as at $400{ }^{\circ} \mathrm{C}$ with heating rates of 5 and $10{ }^{\circ} \mathrm{C} \min ^{-1}$ are presented in Fig. 5. The average diameters of the uncalcined and calcined fibers were $1.2 \mu \mathrm{m}$ and $580 \mathrm{~nm}$, respectively. Irrespective of the calcination temperature, the

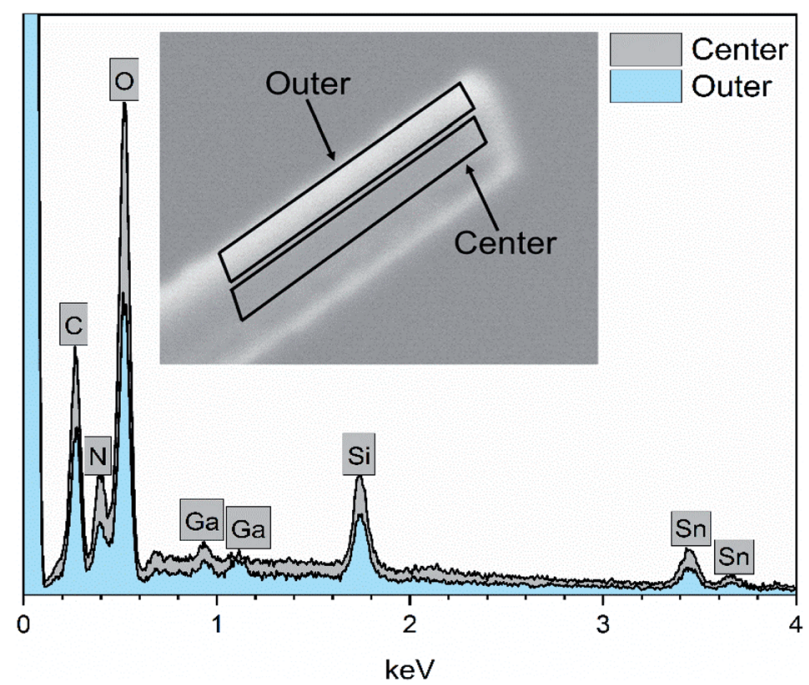

Fig. 7 EDX spectra of a single $\mathrm{SnO}_{2} / \mathrm{SiO}_{2}$ composite fiber calcined at $500{ }^{\circ} \mathrm{C}$ measured at the longitudinal cross-section surface. Ga peaks are due to the ion beam used for fiber milling.
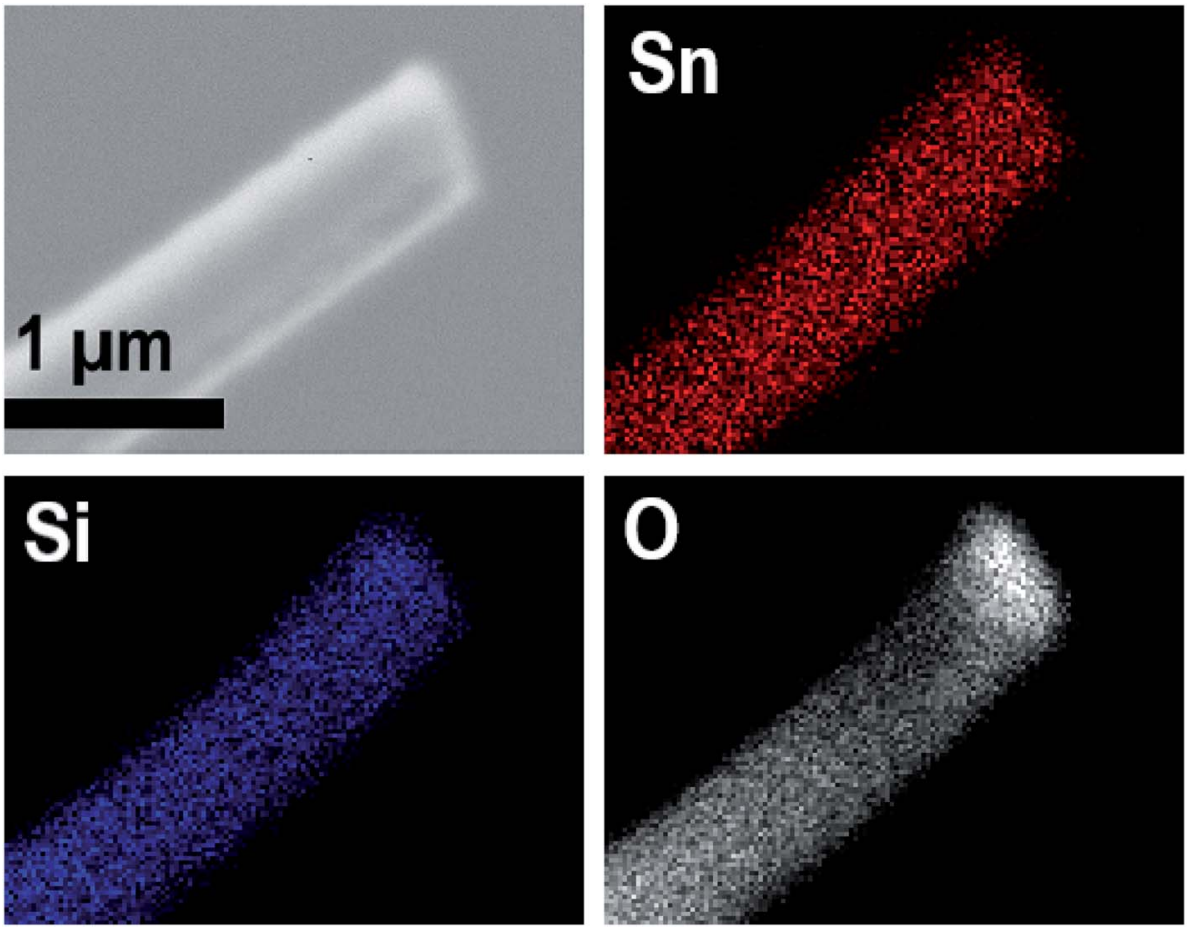

Fig. 6 EDX elemental maps of a single $\mathrm{SnO}_{2} / \mathrm{SiO}_{2}$ composite fiber calcined at $500{ }^{\circ} \mathrm{C}$. 


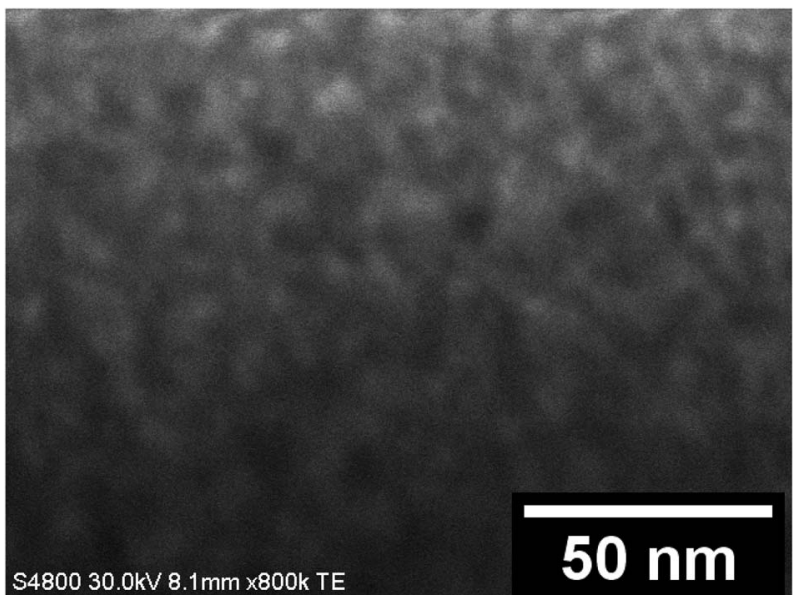

Fig. 8 A TE image of the inner section of a single $\mathrm{SnO}_{2} / \mathrm{SiO}_{2}$ composite fiber calcined at $500^{\circ} \mathrm{C}$.

appearance of the fibers calcined with a heating rate of $1{ }^{\circ} \mathrm{C} \min ^{-1}$ was the same (Fig. $5 \mathrm{~b}-\mathrm{h}$ ). The fibers seemed to have a smooth core that was rather sparsely covered with roundish grains approximately $30 \mathrm{~nm}$ in diameter. A rather similar structure comprising a smooth core and granular surface has been reported previously for $\mathrm{SnO}_{2} / \mathrm{SiO}_{2}$ nanofibers, although with a higher proportion of Si from 50 to $83 \mathrm{~mol} \%$ compared to ours of $25 \mathrm{~mol} \% .^{24}$ As for the fibers calcined with the faster heating rates, they also had a smooth core sparsely covered with grains that were quite angular in shape and rather large (Fig. 5k-n). The average diameter of the grains was $c a .200 \mathrm{~nm}$ in the fibers calcined with heating rates of 5 and $10{ }^{\circ} \mathrm{C} \mathrm{min}^{-1}$,

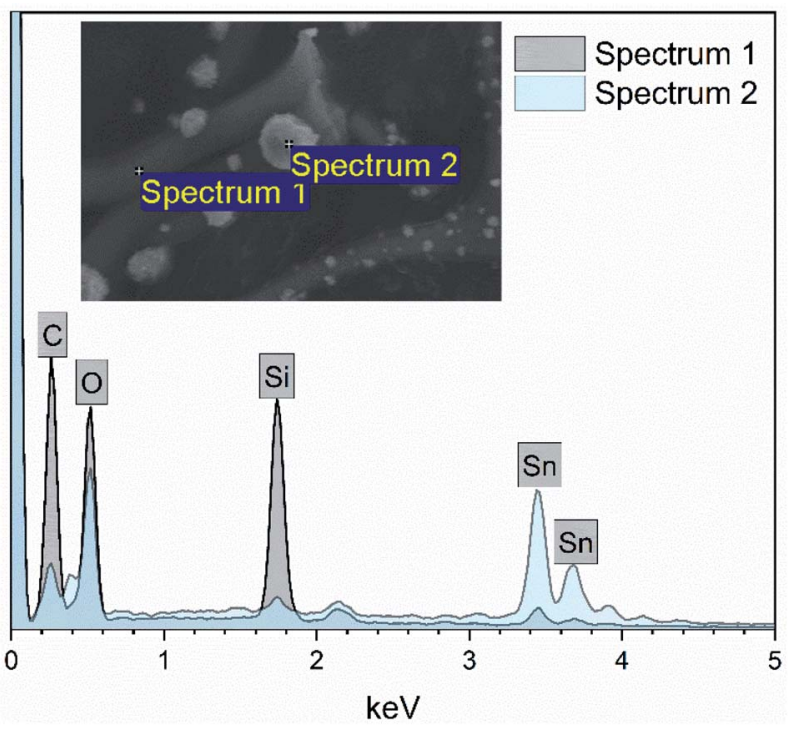

Fig. 10 EDX spectra measured at the smooth part (spectrum 1) and surface grain (spectrum 2) of a single $\mathrm{SnO}_{2} / \mathrm{SiO}_{2}$ composite fiber calcined at $400{ }^{\circ} \mathrm{C}$ with a heating rate of $10{ }^{\circ} \mathrm{C} \mathrm{min}$.

although there was some variation between individual fibers. Among the fibers calcined at $500{ }^{\circ} \mathrm{C}$ with the slow heating rate of $1{ }^{\circ} \mathrm{C} \min ^{-1}$, there were also some fibers with a special morphology with the fiber core covered with large, irregular grains of $500 \mathrm{~nm}$ to $1 \mu \mathrm{m}$ in diameter (Fig. 5i and j). FESEM (Fig. 5h) and TE imaging (Fig. 4c and d) confirmed that the structure of the $\mathrm{SnO}_{2} / \mathrm{SiO}_{2}$ composite fibers was dense like that of the bare $\mathrm{SnO}_{2}$ fibers.
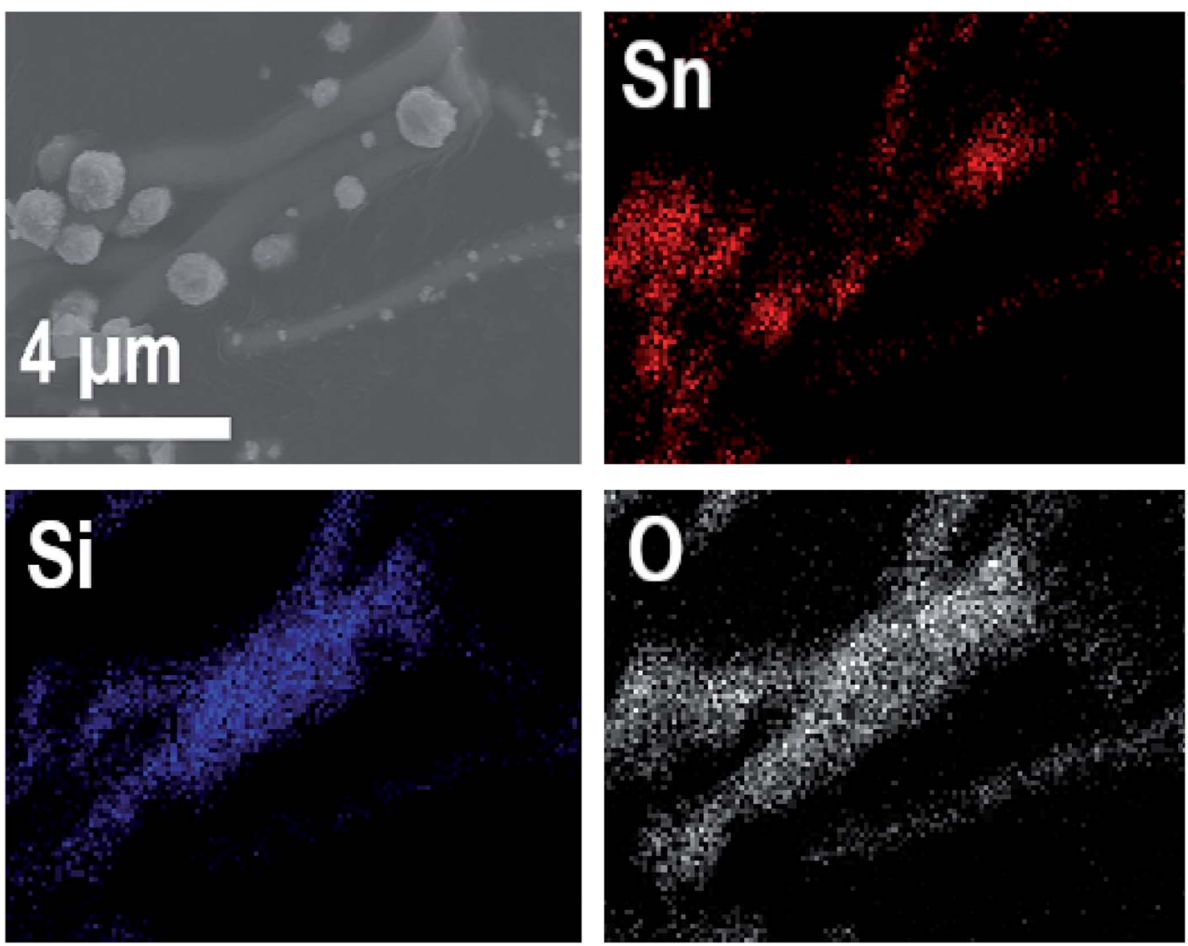

Fig. 9 EDX elemental maps of $\mathrm{SnO}_{2} / \mathrm{SiO}_{2}$ composite fibers calcined at $400{ }^{\circ} \mathrm{C}$ with a heating rate of $10{ }^{\circ} \mathrm{C} \mathrm{min}-1$. 


\subsection{EDX analysis of the $\mathrm{SnO}_{2}$ and $\mathrm{SnO}_{2} / \mathrm{SiO}_{2}$ fibers}

EDX spectra of the $\mathrm{SnO}_{2}$ fibers are shown in Fig. S1 and S3. $\dagger$ As for the $\mathrm{SnO}_{2} / \mathrm{SiO}_{2}$ composite fibers, the quantitative Sn : Si EDX results were 77 at\%: 23 at\% and 80 at\%: 20 at\% for the fibers calcined at 400 and $500{ }^{\circ} \mathrm{C}$, respectively (Fig. S2 and S4 $\dagger$ ). Considering possible variation in sample homogeneity, the results are as expected and indicate a successful synthesis. Owing to the difficult quantification of light elements with EDX and because detected carbon may also originate in the environment, the amount of residual carbon in the fibers could not be reliably determined.

EDX elemental maps of a single $\mathrm{SnO}_{2} / \mathrm{SiO}_{2}$ fiber calcined at $500{ }^{\circ} \mathrm{C}$ are shown in Fig. 6. EDX spectra recorded from both inner and outer section of the smooth part of the fiber are presented in Fig. 7. A TE image of a thin inner section of the fiber is shown in Fig. 8. For the EDX measurement, a portion of the fiber was FIB milled away to expose a flat longitudinal crosssection surface from which the spectra were recorded. For the TE imaging, equal longitudinal portions from both sides of the fiber were FIB milled away leaving a thin slab in the middle of which the imaging was done. The elemental maps prove the presence of Sn, Si and $\mathrm{O}$ in the fiber but on the basis of them it is difficult to tell any difference between the distribution or the concentration of Sn and Si in the fiber. The EDX spectra of the center and outer smooth parts of the fiber are quite identical and they both show the presence of Sn. This implies that the core of the $\mathrm{SnO}_{2} / \mathrm{SiO}_{2}$ composite fibers in this study is different from the single-phase amorphous $\mathrm{SiO}_{2}$ core reported for the $\mathrm{SnO}_{2} / \mathrm{SiO}_{2}$ composite fibers with a higher proportion of $\mathrm{Si}^{24}$ The TE image from inside the fiber supports this as it suggests that the inner part of the fiber is not homogeneous but consists of distinct nanoscale domains, possibly small $\mathrm{SnO}_{2}$ grains embedded in $\mathrm{a} \mathrm{SiO}_{2}$ matrix. Previously it has been proved that more than ca. 1 mol\% of $\mathrm{SnO}_{2}$ cannot be dissolved in $\mathrm{SiO}_{2}$ but $\mathrm{SnO}_{2}$ forms crystalline nanoclusters dispersed in amorphous $\mathrm{SiO}_{2} \cdot{ }^{57,58}$

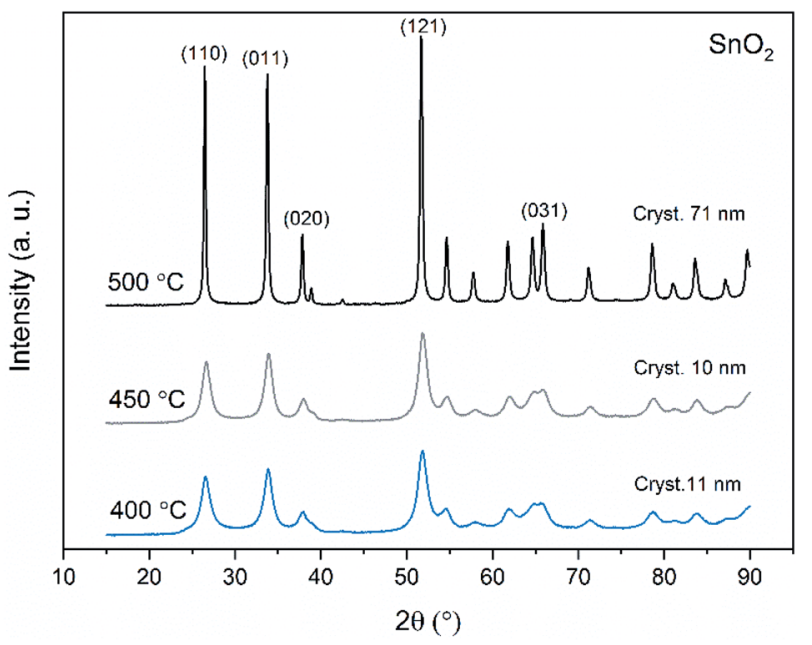

Fig. 11 X-ray diffraction patterns of the $\mathrm{SnO}_{2}$ fibers calcined at 400 , 450 and $500{ }^{\circ} \mathrm{C}$. Cryst. refers to average crystallite size in this and Fig. 12 and 13 .

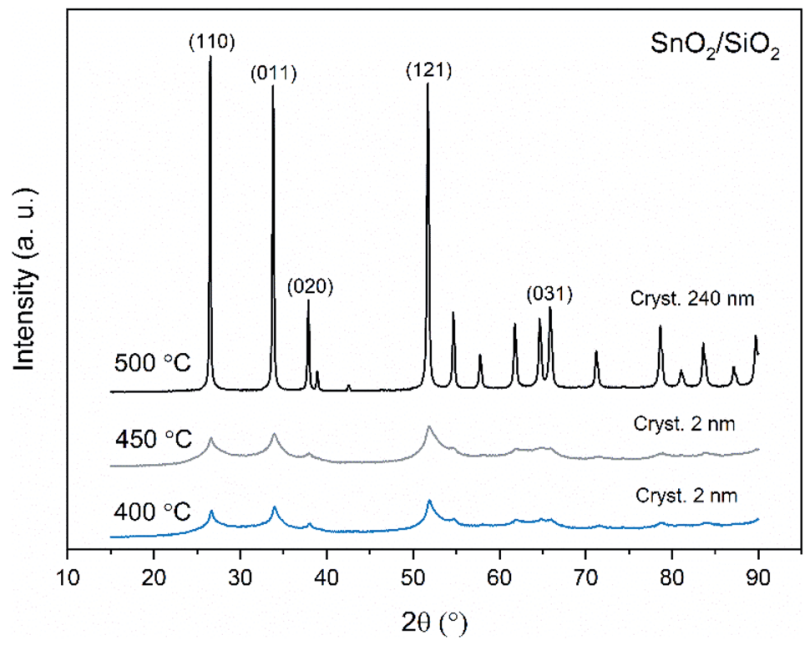

Fig. $12 X$-ray diffraction patterns of the $\mathrm{SnO}_{2} / \mathrm{SiO}_{2}$ fibers calcined at 400,450 and $500{ }^{\circ} \mathrm{C}$ with a heating rate of $1^{\circ} \mathrm{C} \mathrm{min}^{-1}$.

EDX elemental maps of the $\mathrm{SnO}_{2} / \mathrm{SiO}_{2}$ composite fibers calcined at $400{ }^{\circ} \mathrm{C}$ with a heating rate of $10{ }^{\circ} \mathrm{C} \mathrm{min}^{-1}$ are presented in Fig. 9. As can be seen, $\mathrm{Sn}$ is more concentrated at the sites where the large grains are located while $\mathrm{Si}$ is more concentrated at the smooth part of the fibers. This implies that the large grains on the surface of the fibers consist primarily of $\mathrm{SnO}_{2}$. More evidence is provided by EDX spectra (Fig. 10) recorded at the smooth part (spectrum 1) and at a surface grain (spectrum 2) of the fibers. In the spectrum recorded at the grain there are strong signals for Sn and a very weak signal for Si while in the spectrum recorded at the smooth part the case is the opposite, i.e. the signal for Si is very intense and the signals for Sn are quite low.

\subsection{Crystal structure of the $\mathrm{SnO}_{2}$ and $\mathrm{SnO}_{2} / \mathrm{SiO}_{2}$ fibers}

X-ray diffraction patterns of both bare $\mathrm{SnO}_{2}$ and composite $\mathrm{SnO}_{2} / \mathrm{SiO}_{2}$ fibers are presented in Fig. 11-13. All the fibers

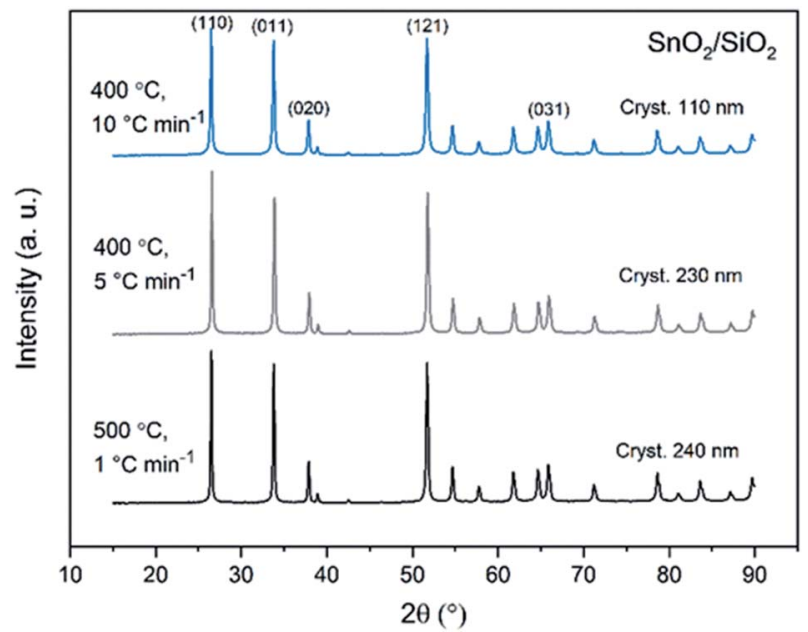

Fig. 13 X-ray diffraction patterns of the $\mathrm{SnO}_{2} / \mathrm{SiO}_{2}$ fibers calcined at $500{ }^{\circ} \mathrm{C}$ with a heating rate of $1^{\circ} \mathrm{C} \mathrm{min}^{-1}$ and at $400{ }^{\circ} \mathrm{C}$ with heating rates of 5 and $10{ }^{\circ} \mathrm{C} \mathrm{min}^{-1}$. 
irrespective of the calcination temperature or heating rate have the tetragonal rutile structure. The presence of $\mathrm{SiO}_{2}$ doesn't seem to affect the crystalline phase nor the lattice parameters compared to bare $\mathrm{SnO}_{2}$ fibers but instead it affects the crystallite size. Interestingly, in both $\mathrm{SnO}_{2}$ and $\mathrm{SnO}_{2} / \mathrm{SiO}_{2}$ fibers there were crystallites of two different sizes for which the weight ratios were determined (Table 1). Refining the XRD data with a single crystallite size led to unsatisfactory results while clear improvement was achieved by using two different crystallite sizes with varying weight ratios. This was pronounced with the composite fibers. However, the bimodal size distribution may not be sufficient and a more complex distribution is probable, but from the perspective of this study it is adequate to show that there are at least two different crystallite sizes present. The fraction of one size was always much higher than that of the other size, ranging from 63 to $93 \mathrm{wt} \%$. In all the fibers the larger crystallites were predominant over the smaller ones, except for the composite fibers calcined at 400 and $450{ }^{\circ} \mathrm{C}$ with a heating rate of $1{ }^{\circ} \mathrm{C} \mathrm{min}^{-1}$ (Fig. $5 \mathrm{~b}-\mathrm{e}$ ). The sizes of the proportionally larger crystallites varied between 10 and $243 \mathrm{~nm}$; the fibers calcined at 400 and $450{ }^{\circ} \mathrm{C}$ with slow heating possessed the smallest of them and the fibers calcined at $500{ }^{\circ} \mathrm{C}$ or at $400{ }^{\circ} \mathrm{C}$ with fast heating the largest of them. The sizes of the proportionally smaller crystallites varied from 2 to $15 \mathrm{~nm}$ and also here the size followed calcination temperature and heating rate: the fibers calcined at 400 and $450{ }^{\circ} \mathrm{C}$ with slow heating possessed the smallest of them and the fibers calcined at $500{ }^{\circ} \mathrm{C}$ or at $400{ }^{\circ} \mathrm{C}$ with fast heating the largest of them. Rietveld refined Xray diffractograms of $\mathrm{SnO}_{2}$ and $\mathrm{SnO}_{2} / \mathrm{SiO}_{2}$ fibers calcined at $500{ }^{\circ} \mathrm{C}$ are presented in Fig. S13 and S14. $\dagger$

The crystallites in the $\mathrm{SnO}_{2}$ fibers calcined at 400 and $450{ }^{\circ} \mathrm{C}$ are in average 11 and $10 \mathrm{~nm}$ in size, respectively, whereas in the corresponding $\mathrm{SnO}_{2} / \mathrm{SiO}_{2}$ fibers they are only $2 \mathrm{~nm}$ in size. The silica in the composite fibers probably acts as a crystal growth inhibitor, as is also the case with $\mathrm{SnO}_{2}$ nanoparticles embedded in a $\mathrm{SiO}_{2}$ network. ${ }^{59}$ It should be noted though that the refinement results of the broad bumps in this data (Fig. 12) leading to below $10 \mathrm{~nm}$ sized crystallites represent rather the lack of long range order than an actual precise size, since severe overlapping of the peaks showing poor crystallinity undermines the accuracy of the results. In both the bare and composite fibers, the average crystallite size increases substantially as the calcination temperature is increased and in the composite fibers the increase is quite steep (Table 1). It is known that the crystallite size of ceramic submicron fibers depends on the calcination temperature. ${ }^{44}$ In the bare $\mathrm{SnO}_{2}$ fibers, the crystallite growth is probably accompanied with a grain growth at the higher temperatures ${ }^{21}$ although no prominent difference in grain size between the fibers calcined at 400,450 and $500{ }^{\circ} \mathrm{C}$ was observed on the basis of the FESEM analysis (Fig. 3). As for the composite fibers calcined at $500{ }^{\circ} \mathrm{C}$ with a heating rate of $1{ }^{\circ} \mathrm{C} \mathrm{min}^{-1}$ and at $400{ }^{\circ} \mathrm{C}$ with heating rates of 5 and $10{ }^{\circ} \mathrm{C} \mathrm{min}^{-1}$, both the high calcination temperature and fast heating rates could explain the large crystallite sizes of 243, 230 and $111 \mathrm{~nm}$, respectively (Table 1). It is likely that the large, irregular grains on the fibers (Fig. 5i-n) consist mainly of $\mathrm{SnO}_{2}$ that is known to form various shapes in nanoscale.$^{50,60}$ High calcination temperatures and fast
Table 1 Average crystallite sizes of the $\mathrm{SnO}_{2}$ and $\mathrm{SnO}_{2} / \mathrm{SiO}_{2}$ fibers and weight ratios of small (low crystallinity) and large (high crystallinity) crystallites. Calc. param. refer to calcination parameters, i.e. calcination temperature and heating rate. The calcination duration was $4 \mathrm{~h}$

\begin{tabular}{|c|c|c|c|c|}
\hline Fibers & Calc. param. & Crystallinity & $\begin{array}{l}\text { Av. cryst. } \\
\text { size (nm) }\end{array}$ & $\mathrm{Wt} \%$ \\
\hline $\mathrm{SnO}_{2}$ & $400{ }^{\circ} \mathrm{C}, 1{ }^{\circ} \mathrm{C} \min ^{-1}$ & High/low & $11 / 3$ & $63 / 37$ \\
\hline $\mathrm{SnO}_{2}$ & $450{ }^{\circ} \mathrm{C}, 1{ }^{\circ} \mathrm{C} \min ^{-1}$ & High/low & $10 / 2$ & $93 / 7$ \\
\hline $\mathrm{SnO}_{2}$ & $500{ }^{\circ} \mathrm{C}, 1{ }^{\circ} \mathrm{C} \min ^{-1}$ & High/low & $71 / 12$ & $87 / 13$ \\
\hline $\mathrm{SnO}_{2} / \mathrm{SiO}_{2}$ & $400{ }^{\circ} \mathrm{C}, 1{ }^{\circ} \mathrm{C} \min ^{-1}$ & Low/high & $2 / 14$ & $83 / 17$ \\
\hline $\mathrm{SnO}_{2} / \mathrm{SiO}_{2}$ & $450{ }^{\circ} \mathrm{C}, 1{ }^{\circ} \mathrm{C} \min ^{-1}$ & Low/high & $2 / 11$ & $80 / 20$ \\
\hline $\mathrm{SnO}_{2} / \mathrm{SiO}_{2}$ & $500{ }^{\circ} \mathrm{C}, 1^{\circ} \mathrm{C} \min ^{-1}$ & High/low & $243 / 11$ & $79 / 21$ \\
\hline $\mathrm{SnO}_{2} / \mathrm{SiO}_{2}$ & $400{ }^{\circ} \mathrm{C}, 5^{\circ} \mathrm{C} \min ^{-1}$ & High/low & $230 / 15$ & $74 / 26$ \\
\hline $\mathrm{SnO}_{2} / \mathrm{SiO}_{2}$ & $400{ }^{\circ} \mathrm{C}, 10{ }^{\circ} \mathrm{C} \mathrm{min}^{-1}$ & High/low & $111 / 9$ & $74 / 26$ \\
\hline
\end{tabular}

heating rates may influence both the size and shape of crystals, ${ }^{61}$ which is reflected in the morphology of grains comprising the crystals.

The presence of crystallites of two different sizes in the $\mathrm{SnO}_{2} /$ $\mathrm{SiO}_{2}$ composite fibers is reasonable in the light of the electron microscopy and EDX analysis results. Based on EDX analysis, both $\mathrm{Sn}$ and $\mathrm{Si}$ are present in the core of the composite fibers but the surface grains consist primarily of $\mathrm{SnO}_{2}$ (Fig. 7, 9 and 10). It is seen in the TEM image (Fig. 8) that the core of the fibers comprises different nanoscale domains probably of $\mathrm{SnO}_{2}$ and $\mathrm{SiO}_{2}$. As discussed, $\mathrm{SiO}_{2}$ in the core of the fibers presumably prevents $\mathrm{SnO}_{2}$ crystallite growth. This might cause the presence of small $\mathrm{SnO}_{2}$ crystallites and grains in the core of the fibers. The $\mathrm{SnO}_{2}$ crystallites can grow more freely on the surface of the fibers resulting in larger crystallite and grain sizes. For the $\mathrm{SnO}_{2} / \mathrm{SiO}_{2}$ fibers calcined at 400 and $450{ }^{\circ} \mathrm{C}$ with a heating rate of $1{ }^{\circ} \mathrm{C} \mathrm{min}{ }^{-1}$ the relatively high amount of small $2 \mathrm{~nm}$ crystallites ( 83 and $80 \mathrm{wt} \%$, respectively, Table 1) and the moderate size of the larger crystallites (14 and $11 \mathrm{~nm}$, respectively, Table 1) are probably due to the low calcination temperature and slow heating rate. As regards the bare $\mathrm{SnO}_{2}$ fibers, the presence of the smaller crystallites ( 3,2 and $12 \mathrm{~nm}$ for the fibers calcined at 400 , 450 and $500{ }^{\circ} \mathrm{C}$, respectively, Table 1) might be at least partly due to some PVP residues hindering crystal growth. This may especially be the case for the fibers calcined at the lowest temperature of $400{ }^{\circ} \mathrm{C}$ for which the fraction of the small crystallites, $37 \mathrm{wt} \%$, is the highest of the $\mathrm{SnO}_{2}$ fibers. The average crystallite sizes of 11,10 and $12 \mathrm{~nm}\left(\mathrm{SnO}_{2}\right.$, Table 1$)$ as well as 14 , 11 and $11 \mathrm{~nm}\left(\mathrm{SnO}_{2} / \mathrm{SiO}_{2}\right.$, Table 1$)$ for the fibers calcined at 400 , 450 and $500{ }^{\circ} \mathrm{C}$ with slow heating, respectively, coincide with some $\mathrm{SnO}_{2}$ grain sizes seen in the FESEM images (Fig. 3d, e, g, i and $5 \mathrm{c}, \mathrm{e}, \mathrm{g}$ ). Previously it has been found that the crystal size of granular polycrystalline $\mathrm{SnO}_{2}$ nanofibers is approximately the same as the size of the $\mathrm{SnO}_{2}$ grains meaning that each $\mathrm{SnO}_{2}$ grain is possibly a single crystal. ${ }^{26}$ Perhaps this is the case for some $\mathrm{SnO}_{2}$ grains in the fibers of this study as well.

\subsection{Specific surface area, pore volume and pore size analysis of the $\mathrm{SnO}_{2}$ fibers}

Specific surface area of the $\mathrm{SnO}_{2}$ fibers calcined at $500{ }^{\circ} \mathrm{C}$ was analysed by the Brunauer-Emmett-Teller (BET) method and 
total pore volume, pore size distribution and average pore diameter by the Barrett-Joyner-Halenda (BJH) method using nitrogen gas adsorption and desorption. The specific surface area, total pore volume and average pore size of the fibers were $41 \mathrm{~m}^{2} \mathrm{~g}^{-1}, 0.15 \mathrm{~cm}^{3} \mathrm{~g}^{-1}$ and $10 \mathrm{~nm}$, respectively. The surface area of the fibers is somewhat higher than that found in literature for both dense ${ }^{51}$ and hollow ${ }^{56,62}$ electrospun $\mathrm{SnO}_{2}$ fibers calcined at 500 or $600{ }^{\circ} \mathrm{C}, 6.9$ to $36 \mathrm{~m}^{2} \mathrm{~g}^{-1}$. The same is true of the total pore volume, as a smaller pore volume of $0.079 \mathrm{~cm}^{3} \mathrm{~g}^{-1}$ has been reported by Mudra et al. ${ }^{62}$ while a larger average pore size of $16 \mathrm{~nm}$ has been reported by Xia et al. ${ }^{56}$ The surface area of the $\mathrm{SnO}_{2}$ fibers is quite high considering the large $71 \mathrm{~nm}$ crystallites, as large crystallites commonly result in a small surface area. For $\mathrm{ZrO}_{2}$ fibers of almost the same diameter (570 $\mathrm{nm}$ ) crystallites of 9 and $63 \mathrm{~nm}$ produced surface areas of 14 and $1.7 \mathrm{~m}^{2} \mathrm{~g}^{-1}$, respectively. ${ }^{44}$ The large surface area of the $\mathrm{SnO}_{2}$ fibers of this study can probably be explained by the granular and porous structure. The average pore size of $10 \mathrm{~nm}$ seems to match quite well with the occasional interstices between the grains of the fibers (Fig. 3d, e, $\mathrm{g}$ and i). $\mathrm{N}_{2}$ adsorption and desorption isotherms and pore size distribution of the $\mathrm{SnO}_{2}$ fibers are presented in Fig. S15 and S16, $\uparrow$ respectively.

\section{5 $\mathrm{Co}^{2+}$ uptake by the $\mathrm{SnO}_{2}$ and $\mathrm{SnO}_{2} / \mathrm{SiO}_{2}$ fibers}

The adsorption ability of electroblown submicron fibers is greatly affected by their crystal structure and size, morphology and the amount of possible polymer residues. These characteristics, in turn, depend on the calcination temperature. ${ }^{\mathbf{4 4}}$ Therefore, we investigated the effects of calcination temperature and heating rate on the $\mathrm{Co}^{2+}$ uptake by the $\mathrm{SnO}_{2}$ and $\mathrm{SnO}_{2} /$ $\mathrm{SiO}_{2}$ fibers. As revealed by Table 2, all the fibers have a good $\mathrm{Co}^{2+}$ uptake performance with an average uptake of $99.71 \%$ and 99.53\% for $\mathrm{SnO}_{2}$ and $\mathrm{SnO}_{2} / \mathrm{SiO}_{2}$ fibers, respectively. However, there were some differences between the fibers. As seen from the $K_{\mathrm{d}}$ values, the bare $\mathrm{SnO}_{2}$ fibers have somewhat better $\mathrm{Co}^{2+}$ uptake than the $\mathrm{SnO}_{2} / \mathrm{SiO}_{2}$ composite fibers. The $\mathrm{SiO}_{2}$ in the composite fibers seems to impair their $\mathrm{Co}^{2+}$ uptake, although chemisorption of $\mathrm{Co}^{2+}$ on $\mathrm{SiO}_{2}$ is known. ${ }^{63}$ In this study, however, the crystalline $\mathrm{SnO}_{2}$ appears to be the major adsorbent. The high surface area of the $\mathrm{SnO}_{2}$ fibers is likely to enhance the adsorption even more as it should provide plenty of

Table $2{ }^{57} \mathrm{Co}^{2+}$ uptake by the $\mathrm{SnO}_{2}$ and $\mathrm{SnO}_{2} / \mathrm{SiO}_{2}$ fibers in $0.01 \mathrm{M}$ $\mathrm{NaNO}_{3}$ at $\mathrm{pH}$ 6.0. Calc. param. refer to calcination parameters, i.e. calcination temperature and heating rate. The calcination duration was $4 \mathrm{~h}$

\begin{tabular}{|c|c|c|c|}
\hline Fibers & Calc. param. & Uptake (\%) & $K_{\mathrm{d}}\left(\mathrm{mL} \mathrm{g}^{-1}\right)$ \\
\hline $\mathrm{SnO}_{2}$ & $400^{\circ} \mathrm{C}, 1^{\circ} \mathrm{C} \min ^{-1}$ & $99.51 \pm 0.02$ & $173000 \pm 3000$ \\
\hline $\mathrm{SnO}_{2}$ & $450{ }^{\circ} \mathrm{C}, 1{ }^{\circ} \mathrm{C} \min ^{-1}$ & $99.81 \pm 0.02$ & $272000 \pm 4000$ \\
\hline $\mathrm{SnO}_{2}$ & $500{ }^{\circ} \mathrm{C}, 1^{\circ} \mathrm{C} \min ^{-1}$ & $99.82 \pm 0.01$ & $281000 \pm 5000$ \\
\hline $\mathrm{SnO}_{2} / \mathrm{SiO}_{2}$ & $400{ }^{\circ} \mathrm{C}, 1^{\circ} \mathrm{C} \min ^{-1}$ & $99.69 \pm 0.02$ & $163000 \pm 3000$ \\
\hline $\mathrm{SnO}_{2} / \mathrm{SiO}_{2}$ & $450{ }^{\circ} \mathrm{C}, 1{ }^{\circ} \mathrm{C} \min ^{-1}$ & $99.18 \pm 0.02$ & $58100 \pm 1000$ \\
\hline $\mathrm{SnO}_{2} / \mathrm{SiO}_{2}$ & $500{ }^{\circ} \mathrm{C}, 1^{\circ} \mathrm{C} \min ^{-1}$ & $99.28 \pm 0.02$ & $69700 \pm 1300$ \\
\hline $\mathrm{SnO}_{2} / \mathrm{SiO}_{2}$ & $400{ }^{\circ} \mathrm{C}, 5^{\circ} \mathrm{C} \min ^{-1}$ & $99.70 \pm 0.02$ & $168000 \pm 3000$ \\
\hline $\mathrm{SnO}_{2} / \mathrm{SiO}_{2}$ & $400^{\circ} \mathrm{C}, 10^{\circ} \mathrm{C} \min ^{-1}$ & $99.79 \pm 0.02$ & $234000 \pm 4000$ \\
\hline
\end{tabular}

adsorption sites. EDX elemental maps and spectra of the $\mathrm{SnO}_{2}$ and $\mathrm{SnO}_{2} / \mathrm{SiO}_{2}$ fibers calcined at 400 and $500{ }^{\circ} \mathrm{C}$ with a heating rate of $1^{\circ} \mathrm{C} \mathrm{min}^{-1}$ after adsorption of $\mathrm{Co}^{2+}$ are shown in Fig. S5S12. $\dagger$

In regard to the $\mathrm{SnO}_{2}$ and $\mathrm{SnO}_{2} / \mathrm{SiO}_{2}$ fibers calcined with a heating rate of $1{ }^{\circ} \mathrm{C} \mathrm{min}^{-1}$, the calcination temperature had a different effect on their $\mathrm{Co}^{2+}$ uptake performance. Calcination temperatures of 500 and $400{ }^{\circ} \mathrm{C}$ produced the best adsorption performance for $\mathrm{SnO}_{2}$ and $\mathrm{SnO}_{2} / \mathrm{SiO}_{2}$ fibers, respectively (Table 2 and Fig. 14). Lower calcination temperature tends to produce smaller crystallites and thus increase the surface area of the material, which, in turn, improves its adsorption properties. ${ }^{\mathbf{4 4}}$ Therefore it is surprising that the $\mathrm{SnO}_{2}$ fibers calcined at $500{ }^{\circ} \mathrm{C}$ possessing $71 \mathrm{~nm}$ crystallites perform better than the $\mathrm{SnO}_{2}$ fibers calcined at 400 and $450{ }^{\circ} \mathrm{C}$ possessing 11 and $10 \mathrm{~nm}$ crystallites, respectively. One possible reason is that the lower calcination temperatures leave some PVP residues in the material blocking some of the adsorption sites. However, despite their different crystallite size, the $K_{\mathrm{d}}$ value of the $\mathrm{SnO}_{2}$ fibers calcined at $450{ }^{\circ} \mathrm{C}$ is almost as high as that of the fibers calcined at $500{ }^{\circ} \mathrm{C}$. The crystallite size doesn't seem to be a determining factor in the $\mathrm{Co}^{2+}$ uptake performance of the $\mathrm{SnO}_{2}$ fibers.

In the $\mathrm{SnO}_{2} / \mathrm{SiO}_{2}$ fibers calcined with a heating rate of $1{ }^{\circ} \mathrm{C} \mathrm{min}^{-1}$ the $\mathrm{Co}^{2+}$ uptake correlated better with the crystallite size, since the fibers calcined at $400{ }^{\circ} \mathrm{C}$ and with the smallest $2 \mathrm{~nm}$ crystallites performed the best (Table 2 and Fig. 14). It should be noted that although the fibers calcined at $450{ }^{\circ} \mathrm{C}$ also possessed $2 \mathrm{~nm}$ crystallites, their sorption and $K_{\mathrm{d}}$ values were lower. One reason for the weaker $\mathrm{Co}^{2+}$ uptake performance of the $\mathrm{SnO}_{2} / \mathrm{SiO}_{2}$ fibers calcined at 450 and $500{ }^{\circ} \mathrm{C}$ with a heating rate of $1^{\circ} \mathrm{C} \mathrm{min}^{-1}$ could be that due to the higher calcination temperature, they have fewer surface hydroxyl groups that are assumed to play a significant role in the uptake process. As for the fibers calcined at $500{ }^{\circ} \mathrm{C}$, the peculiar morphology of some

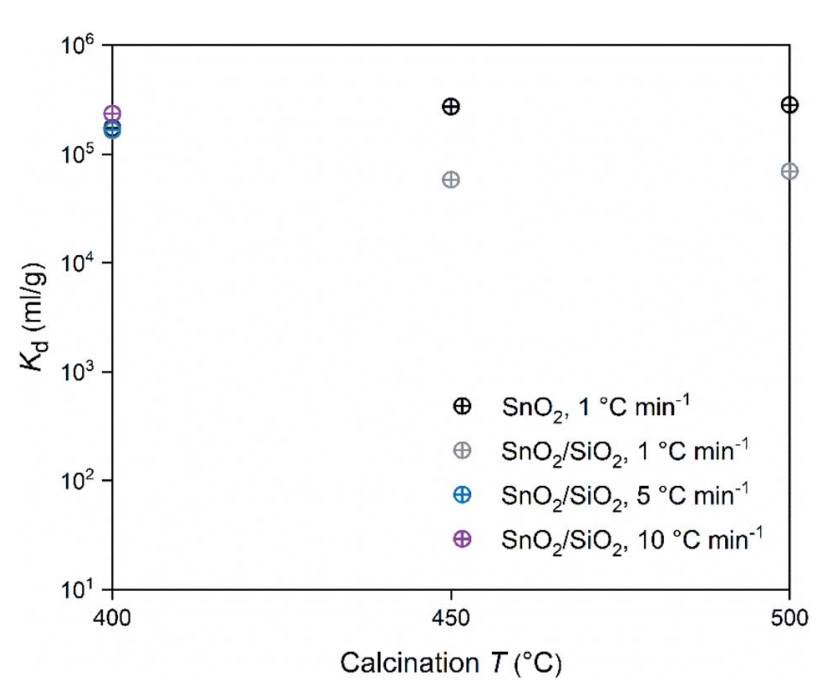

Fig. 14 Distribution coefficient of $30 \mathrm{~Bq} \mathrm{~mL}^{-1}{ }^{57} \mathrm{Co}^{2+}$ on $\mathrm{SnO}_{2}$ and $\mathrm{SnO}_{2} / \mathrm{SiO}_{2}$ fibers as a function of calcination temperature and heating rate in $0.01 \mathrm{M} \mathrm{NaNO}_{3}$ at $\mathrm{pH} 6.0\left(2 \mathrm{~g} \mathrm{~L}^{-1} \mathrm{SnO}_{2}\right.$ or $\left.\mathrm{SnO}_{2} / \mathrm{SiO}_{2}\right)$. 


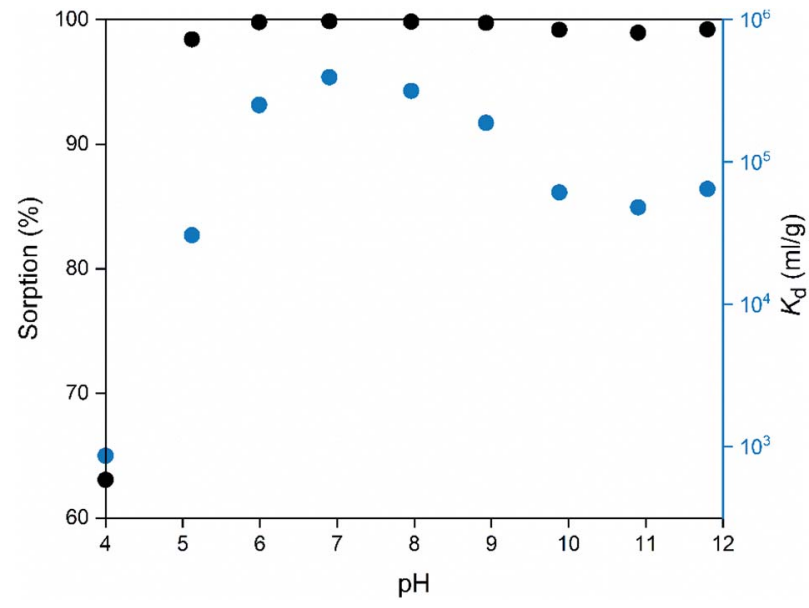

Fig. 15 Sorption and distribution coefficient of $30 \mathrm{~Bq} \mathrm{~mL}^{-1}{ }^{57} \mathrm{Co}^{2+}$ on $\mathrm{SnO}_{2}$ fibers calcined at $500^{\circ} \mathrm{C}$ as a function of $\mathrm{pH}$ in $0.01 \mathrm{M} \mathrm{NaNO}_{3}(2 \mathrm{~g}$ $\mathrm{L}^{-1} \mathrm{SnO}_{2}$ ).

of the fibers (Fig. 5i and j) and large crystallite size of $243 \mathrm{~nm}$ that decreases the surface area, may also impair their $\mathrm{Co}^{2+}$ uptake performance. The $\mathrm{SnO}_{2} / \mathrm{SiO}_{2}$ fibers calcined at $400{ }^{\circ} \mathrm{C}$ with the fast heating rates of 5 and $10{ }^{\circ} \mathrm{C} \mathrm{min}^{-1}$ exhibited excellent $\mathrm{Co}^{2+}$ uptake despite their large crystallite sizes. This might be explained by the roundish shape and quite sparse distribution of their $\mathrm{SnO}_{2}$ grains (Fig. 5k-n) compared to the angular and rather tightly packed $\mathrm{SnO}_{2}$ grains of the fibers calcined at $500{ }^{\circ} \mathrm{C}$ (Fig. 5i and j). The roundish and sparsely distributed surface $\mathrm{SnO}_{2}$ grains might be better accessible to adsorbing ions in an aqueous solution. Moreover, the lower target temperature of $400{ }^{\circ} \mathrm{C}$ may cause more hydroxyl groups remaining on the surface of the fibers enhancing the uptake of $\mathrm{Co}^{2+}$.

The $\mathrm{pH}$ of the solution may have a major impact on the uptake properties of a material because it affects both the

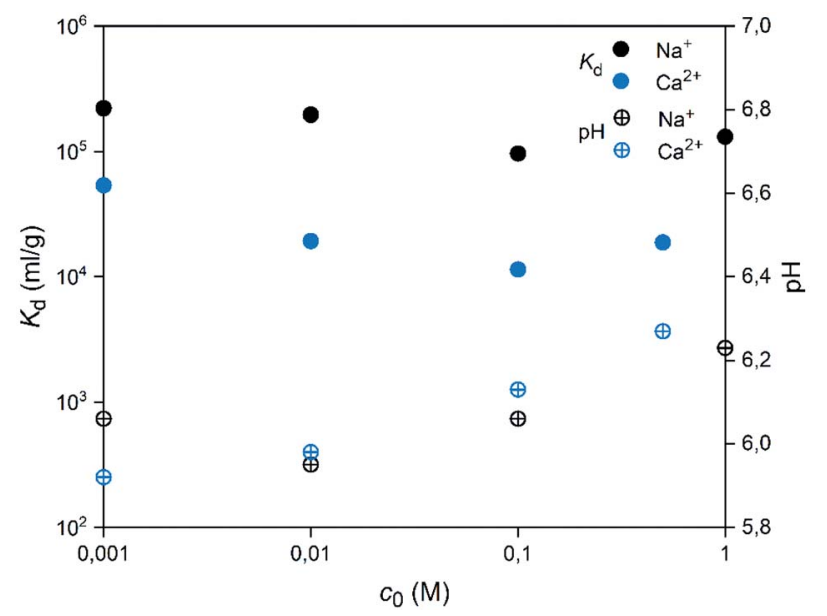

Fig. 16 Effects of concentrations of competing ions $\mathrm{Na}^{+}$or $\mathrm{Ca}^{2+}$ on the uptake of $30 \mathrm{~Bq} \mathrm{~mL}{ }^{-1}{ }^{57} \mathrm{Co}^{2+}$ by $\mathrm{SnO}_{2}$ fibers calcined at $500{ }^{\circ} \mathrm{C}$. The initial $\mathrm{pH}$ was 6 and the $\mathrm{pH}$ at the end of the experiment is shown $\left(2 \mathrm{~g} \mathrm{~L}^{-1} \mathrm{SnO}_{2}\right)$.

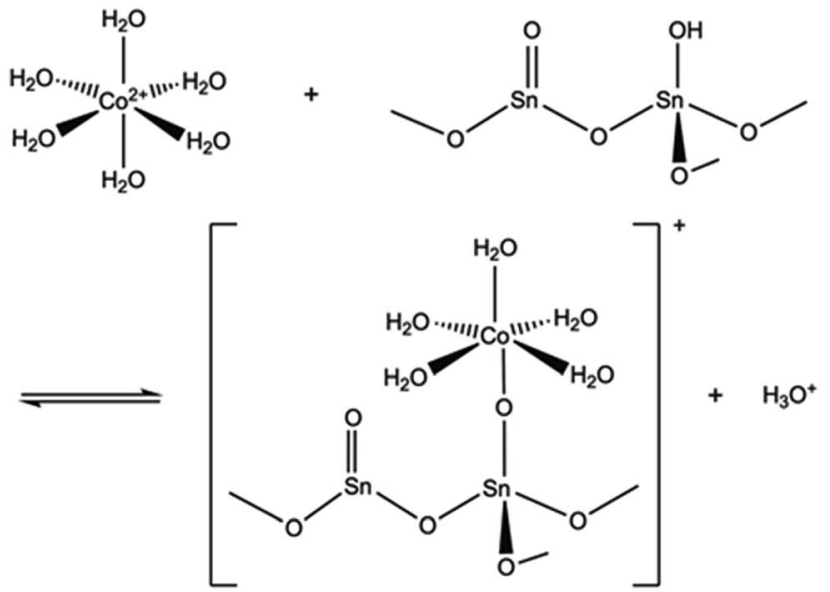

Fig. 17 An assumed ion exchange reaction between $\mathrm{Co}^{2+}$ and a proton of surface hydroxyl group of $\mathrm{SnO}_{2} .^{5}$

speciation of the adsorbate and the surface charge of the adsorbent. As for $\mathrm{Co}^{2+}$, it exists as $\mathrm{Co}\left(\mathrm{H}_{2} \mathrm{O}\right)_{6}{ }^{2+}$ in the $\mathrm{pH}$ range of 2 to $9 .{ }^{64}$ It can be inferred from the $K_{\mathrm{d}}$ values (Fig. 15), that the $\mathrm{SnO}_{2}$ fibers adsorb $\mathrm{Co}^{2+}$ the best in the neutral to mildly basic $\mathrm{pH}$ region, from $\mathrm{pH} 6$ to 9 , and they reach the highest $K_{\mathrm{d}}$ value at the $\mathrm{pH}$ of 7 . This is in accordance with previous research ${ }^{7}$ and promising for the use of the fibers in purification of NPP waste waters, since the $\mathrm{pH}$ of the primary coolant water in NPPs is about 7. The point of zero charge $\left(\mathrm{pH}_{\mathrm{pzc}}\right)$ of $\mathrm{SnO}_{2}$ lies at a $\mathrm{pH}$ of $4,{ }^{7}$ and above this $\mathrm{pH}$ the surface charge of pure $\mathrm{SnO}_{2}$ is negative. The $\mathrm{Co}^{2+}$ uptake by the rutile structured $\mathrm{SnO}_{2}$ is evidently based on electrostatic forces ${ }^{65}$ which explains the good uptake in the neutral to mildly basic $\mathrm{pH}$ region where the charges of the $\mathrm{Co}^{2+}$ species and the surface of the $\mathrm{SnO}_{2}$ fibers are the opposite. The adsorption of $\mathrm{Co}^{2+}$ on hydrous $\mathrm{SnO}_{2}$ most probably occurs via substitution of $\mathrm{H}^{+}$ions of the surface water molecules or hydroxyl groups by $\mathrm{Co}^{2+}$ ions. ${ }^{4-6,66}$ An assumed ion exchange reaction between hydrous $\mathrm{SnO}_{2}$ and $\mathrm{Co}^{2+}$ is illustrated in Fig. $17 .^{5}$

A good selectivity of the adsorbent is crucial when a trace amount of a specific ion is separated from a solution containing much higher concentrations of other ions. Thus, we examined how the $\mathrm{Co}^{2+}$ adsorption on $\mathrm{SnO}_{2}$ fibers is influenced by $\mathrm{Na}^{+}$and $\mathrm{Ca}^{2+}$ ions that are among the most common cations in natural and nuclear waste waters with concentrations of 0.47 and $0.01 \mathrm{M}$ in sea water, respectively. ${ }^{67}$ As Fig. 16 reveals, the $\mathrm{Co}^{2+}$ uptake remains high in the presence of $\mathrm{Na}^{+}$ ions irrespective of their concentration. By contrast, there is a marked weakening of the uptake in the $\mathrm{CaCl}_{2}$ solution at concentrations of $0.01 \mathrm{M}$ or higher. With both of the ions, the interfering effect increases with concentration up to $0.1 \mathrm{M}$, after which there is no further decreasing effect on the uptake of $\mathrm{Co}^{2+}$. The good selectivity of the fibers for $\mathrm{Co}^{2+}$ over $\mathrm{Na}^{+}$is promising for their use in decontamination of radioactive waste water, since $\mathrm{Na}^{+}$is the most abundant coexisting ion in nuclear waste effluents. ${ }^{67}$ 


\section{Conclusions}

We have synthesized $\mathrm{SnO}_{2}$ and composite $\mathrm{SnO}_{2} / \mathrm{SiO}_{2}$ submicron fibers with a Sn : Si molar ratio of $3: 1$ and studied the ability of the fibers to remove $\mathrm{Co}^{2+}$ from an aqueous solution. For the synthesis, a novel and efficient electroblowing method was used. The as-electroblown fibers were calcined in air at 400, 450 and $500{ }^{\circ} \mathrm{C}$ with varying heating rates in order to produce the desired ceramic material and to investigate the effect of calcination temperature and heating rate on the structure and $\mathrm{Co}^{2+}$ uptake by the fibers. The bare $\mathrm{SnO}_{2}$ fibers had a granular structure in the tetragonal rutile phase with an average diameter of $560 \mathrm{~nm}$. The $\mathrm{SnO}_{2} / \mathrm{SiO}_{2}$ composite fibers had a smooth core possibly comprising small $\mathrm{SnO}_{2}$ grains in a $\mathrm{SiO}_{2}$ matrix with large $\mathrm{SnO}_{2}$ grains dispersed on the core and the average diameter of the fibers was $580 \mathrm{~nm}$. The morphology of the surface $\mathrm{SnO}_{2}$ grains of the composite fibers was dependent on the calcination temperature and heating rate. Irrespective of the calcination temperature, a heating rate of $1{ }^{\circ} \mathrm{C} \mathrm{min}^{-1}$ yielded surface $\mathrm{SnO}_{2}$ grains that were roundish and ca. $30 \mathrm{~nm}$ in diameter. In the composite fibers calcined at $500{ }^{\circ} \mathrm{C}$ with a heating rate of $1^{\circ} \mathrm{C} \mathrm{min}^{-1}$ or at $400{ }^{\circ} \mathrm{C}$ with faster heating rates of 5 and $10{ }^{\circ} \mathrm{C} \mathrm{min}{ }^{-1}$ there were also some surface $\mathrm{SnO}_{2}$ grains that were irregularly shaped and $200 \mathrm{~nm}$ to $1 \mu \mathrm{m}$ in diameter.

Both bare $\mathrm{SnO}_{2}$ and composite $\mathrm{SnO}_{2} / \mathrm{SiO}_{2}$ fibers had a high $\mathrm{Co}^{2+}$ uptake with $\mathrm{SnO}_{2}$ fibers exhibiting slightly more efficient $\mathrm{Co}^{2+}$ separation. Calcination temperature and heating rate affected the $\mathrm{Co}^{2+}$ uptake by the fibers. Among the $\mathrm{SnO}_{2}$ fibers, the fibers calcined at $500{ }^{\circ} \mathrm{C}$ performed the best. Among the composite fibers, the fibers calcined at $400{ }^{\circ} \mathrm{C}$ performed the best, and within them the fibers calcined with a heating rate of $10{ }^{\circ} \mathrm{C} \min ^{-1}$ were superior to the fibers calcined with heating rates of 1 and $5{ }^{\circ} \mathrm{C} \mathrm{min}{ }^{-1}$. The $\mathrm{SnO}_{2} / \mathrm{SiO}_{2}$ composite fibers were more elastic and durable and easier to handle than the somewhat brittle $\mathrm{SnO}_{2}$ fibers which makes them ideal for use in flowthrough separation columns. Overall, on the basis of our results, the mechanical strength of $\mathrm{SnO}_{2}$ submicron fibers can be enhanced by adding a moderate amount of $\mathrm{SiO}_{2}$ without compromising their adsorption performance too much. This approach might also be extended to other ceramic submicron and nanofibers that require improved mechanical properties in various applications.

\section{Author contributions}

J. P.: conceptualization, methodology, investigation, data curation, formal analysis, validation, visualization, writing - original draft. S. W.: investigation. S. L.: investigation, formal analysis. M. H.: formal analysis. M. V.: investigation, formal analysis. M. K.: investigation, formal analysis. T. H.: investigation, formal analysis. M. R.: funding acquisition, supervision, writing - review \& editing. R. K.: funding acquisition, supervision, writing - review \& editing.

\section{Conflicts of interest}

There are no conflicts of interest to declare.

\section{Acknowledgements}

J. Paajanen and S. Lönnrot are grateful to Fortum Power and Heat Oy for financial support for the research. Kaisu Ainassaari is thanked for conducting the BET and BJH analyses.

\section{References}

1 P. Yang, The Chemistry of Nanostructured Materials, World Scientific, Singapore, 2003.

2 A. Clearfield, Inorganic Ion Exchange Materials, CRC Press, Boca Raton, Florida, 1982.

3 E. Abdelkader, L. Nadjia and V. Rose-Noelle, Int. J. Ind. Chem., 2016, 7, 53.

4 J. D. Donaldson and M. J. Fuller, J. Inorg. Nucl. Chem., 1968, 30, 1083.

5 N. Jaffrezic-Renault, J. Inorg. Nucl. Chem., 1978, 40, 539.

6 N. Z. Misak, E. I. Shabana, E. M. Mikhail and H. F. Ghoneimy, React. Polym., 1992, 16, 261.

7 R. Rãutiu and D. A. White, Solvent Extr. Ion Exch., 1996, 14, 721.

8 D. A. White and R. Rãutiu, Chem. Eng. J., 1997, 66, 85.

9 A. Lagashetty and A. Venkataraman, Bull. Mater. Sci., 2004, 27, 491.

10 R. Koivula and R. Harjula, Presented in part at Waste management 2007 Conference, Tucson, Arizona, USA, 25 Feb. to 1 Mar., 2007.

11 A. Nilchi, T. Shariati Dehaghan and S. Rasouli Garmarodi, Desalination, 2013, 321, 67.

12 K. Yogesh Kumar, T. N. Vinuth Raj, S. Archana, S. B. Benaka Prasad, S. Olivera and H. B. Muralidhara, Journal of Water Process Engineering, 2016, 13, 44.

13 S. Haq, W. Rehman, M. Waseem, M. Rehman and K. H. Shah, J. Inorg. Organomet. Polym. Mater., 2020, 30, 1197.

14 R. E. Presley, C. L. Munsee, C.-H. Park, D. Hong, J. F. Wager and D. A. Keszler, J. Phys. D: Appl. Phys., 2004, 37, 2810.

15 A. P. Rizzato, C. V. Santilli, S. H. Pulcinelli, Y. Messaddeq and P. Hammer, J. Sol-Gel Sci. Technol., 2004, 32, 155.

16 Y. Wang, X. Jiang and Y. Xia, J. Am. Chem. Soc., 2003, 125, 16176.

17 N. Pinna, G. Neri, M. Antonietti and M. Niederberger, Angew. Chem., Int. Ed., 2004, 43, 4345.

18 Y. Wang, I. Ramos and J. J. Santiago-Aviles, IEEE Sens. J., 2007, 7, 1347.

19 Y. Zhang, X. He, J. Li, Z. Miao and F. Huang, Sens. Actuators, $B, 2008,132,67$.

20 Y. Zhang, J. Li, G. An and X. He, Sens. Actuators, B, 2010, 144, 43.

21 J. Y. Park, K. Asokan, S.-W. Choi and S. S. Kim, Sens. Actuators, B, 2011, 152, 254.

22 R. Ab Kadir, Z. Li, A. Z. Sadek, R. Abdul Rani, A. S. Zoolfakar, M. R. Field, J. Z. Ou, A. F. Chrimes and K. Kalantar-Zadeh, J. Phys. Chem. C, 2014, 118, 3129.

23 J. P. Santos, M. J. Fernández, J. L. Fontecha, D. Matatagui, I. Sayago, M. C. Horrillo and I. Gracia, Sensors, 2014, 14, 24231. 
24 Y. Liu, P. Yang, J. Li, K. Matras-Postolek, Y. Yue and B. Huang, RSC Adv., 2016, 6, 13371.

25 S. Gunji, M. Jukei, Y. Shimotsuma, K. Miura, K. Suematsu, K. Watanabe and K. Shimanoe, J. Mater. Chem. C, 2017, 5, 6369.

26 Z. Yang, G. Du, C. Feng, S. Li, Z. Chen, P. Zhang, Z. Guo, X. Yu, G. Chen, S. Huang and H. Liu, Electrochim. Acta, 2010, 55, 5485.

27 G. Granger, C. Restoin, P. Roy, R. Jamier, S. Rougier, J.-R. Duclere, A. Lecomte, R. Dauliat and J.-M. Blondy, Micro-Structured and Specialty Optical Fibres IV, 2015, vol. 9507, p. 95070J.

28 H. Shan, X. Wang, F. Shi, J. Yan, J. Yu and B. Ding, ACS Appl. Mater. Interfaces, 2017, 9, 18966.

29 L. A. Malik, A. Bashir, A. Qureashi and A. H. Pandith, Environ. Chem. Lett., 2019, 17, 1495.

30 S. Muthusaravanan, N. Sivarajasekar, J. S. Vivek, T. Paramasivan, M. Naushad, J. Prakashmaran, V. Gayathri and O. K. Al-Duaij, Environ. Chem. Lett., 2018, 16, 1339.

31 T. S. Anirudhan, F. Shainy and J. R. Deepa, Chem. Ecol., 2019, $35,235$.

32 M. Naushad, Z. A. ALOthman, Md. R. Awual, M. M. Alam and G. E. Eldesoky, Ionics, 2015, 21, 2237.

33 K. Vijayaraghavan, S. Rangabhashiyam, T. Ashokkumar and J. Arockiaraj, Sep. Sci. Technol., 2016, 51, 2725.

34 S. Lönnrot, V. Suorsa, J. Paajanen, T. Hatanpää, M. Ritala and R. Koivula, RSC Adv., 2019, 9, 22355.

35 S. Ramakrishna, K. Fujihara, W.-E. Teo, T.-C. Lim and Z. Ma, An Introduction to Electrospinning and Nanofibers, World Scientific, Singapore, 2005.

36 S. Thenmozhi, N. Dharmaraj, K. Kadirvelu and H. Y. Kim, Mater. Sci. Eng., B, 2017, 217, 36.

37 Elmarco, https://elmarco.com/, accessed January 2021.

38 Fanavaran Nano-Meghyas (Fnm co. Ltd.), http://en.fnm.ir/, accessed January 2021.

39 Inovenso Ltd., https://www.inovenso.com/, accessed January 2021.

40 J. L. Daristotle, A. M. Behrens, A. D. Sandler and P. Kofinas, ACS Appl. Mater. Interfaces, 2016, 8, 34951.

41 Z. Huang, A. Kolbasov, Y. Yuan, M. Cheng, Y. Xu, R. Rojaee, R. Deivanayagam, T. Foroozan, Y. Liu, K. Amine, J. Lu, A. L. Yarin and R. Shahbazian-Yassar, ACS Appl. Mater. Interfaces, 2020, 12, 16200.

42 W. Tutak, S. Sarkar, S. Lin-Gibson, T. M. Farooque, G. Jyotsnendu, D. Wang, J. Kohn, D. Bolikal and C. G. Simon Jr., Biomaterials, 2013, 34, 2389.

43 E. N. Bolbasov, K. S. Stankevich, E. A. Sudarev, V. M. Bouznik, V. L. Kudryavtseva, L. V. Antonova, V. G. Matveeva, Y. G. Anissimov and S. I. Tverdokhlebov, Mater. Chem. Phys., 2016, 182, 338.

44 J. Paajanen, S. Lönnrot, M. Heikkilä, K. Meinander, M. Kemell, T. Hatanpää, K. Ainassaari, M. Ritala and R. Koivula, Nanoscale Adv., 2019, 1, 4373.
45 I. C. Um, D. Fang, B. S. Hsiao, A. Okamoto and B. Chu, Biomacromolecules, 2004, 5, 1428.

46 H.-Y. Hsiao, C.-M. Huang, Y.-Y. Liu, Y.-C. Kuo and H. Chen, J. Appl. Polym. Sci., 2012, 124, 4904.

47 WWW Table of Radioactive Isotopes, http:// nucleardata.nuclear.lu.se/toi/nuclide.asp?iZA $=270060$, accessed January 2021.

48 R. Harjula, J. Lehto, A. Paajanen and L. Brodkin, presented in part at Waste Management'99 Conference, Tucson, Arizona, USA 28 Feb.-4 Mar, 1999.

49 J. Holopainen and M. Ritala, J. Eur. Ceram. Soc., 2016, 36, 3219.

50 S. Santibenchakul, S. Chaiyasith and W. Pecharapa, Integr. Ferroelectr., 2016, 175, 130.

51 A. S. Reynolds, T. H. Pierre, R. McCall, J. Wu and W. E. Gato, J. Environ. Sci. Health, Part A: Toxic/Hazard. Subst. Environ. Eng., 2018, 53, 986.

52 L. Lutterotti, D. Chateigner, S. Ferrari and J. Ricote, Thin Solid Films, 2004, 450, 34.

53 E. Santala, R. Koivula, R. Harjula and M. Ritala, Environ. Technol., 2019, 40, 3561.

54 C. N. Hsiao and K. S. Huang, J. Appl. Polym. Sci., 2005, 96, 1936.

55 L. M. Al-Harbi, S. A. Kosa, M. K. Baloch, Q. A. Bhatti and E. E. H. El-Mossalamy, Int. J. Polym. Sci., 2016, 2016, 2417292.

56 X. Xia, X. J. Dong, Q. F. Wei, Y. B. Cai and K. Y. Lu, eXPRESS Polym. Lett., 2012, 6, 169.

57 N. Chiodini, F. Meinardi, F. Morazzoni, J. Padovani, A. Paleari, R. Scotti and G. Spinolo, J. Mater. Chem., 2001, 11, 926.

58 B. I. Denker, B. I. Galagan, L. D. Iskhakova, S. E. Sverchkov and E. M. Dianov, Appl. Phys. B: Lasers Opt., 2015, 120, 13.

59 C. Leonhardt, S. Brumm, A. Seifert, G. Cox, A. Lange, T. Ruffer, D. Schaarschmidt, H. Lang, N. Jöhrmann, M. Hietschold, F. Simon and M. Mehring, ChemPlusChem, 2013, 78, 1400.

60 H. Ohgi, T. Maeda, E. Hosono, S. Fujihara and H. Imai, Cryst. Growth Des., 2005, 5, 1079.

61 I. Denry, J. A. Holloway and P. K. Gupta, J. Biomed. Mater. Res., Part B, 2012, 100, 1198.

62 E. Mudra, I. Shepa, O. Milkovic, Z. Dankova, A. Kovalcikova, A. Annušová, E. Majkova and J. Dusza, Appl. Surf. Sci., 2019, 480, 876.

63 R. Trujillano, F. Villain, C. Louis and J.-F. Lambert, J. Phys. Chem. C, 2007, 111, 7152.

64 R. N. Collins and A. S. Kinsela, Chemosphere, 2010, 79, 763. 65 R. Koivula, R. Harjula and J. Lehto, Microporous Mesoporous Mater., 2002, 55, 231.

66 F. Granados, V. Bertin, S. Bulbulian and M. Solache-Ríos, Appl. Radiat. Isot., 2006, 64, 291.

67 J. Lehto, R. Koivula, H. Leinonen, E. Tusa and R. Harjula, Sep. Purif. Rev., 2019, 48, 122. 